\title{
Geochemistry and distribution of sediments in the East Indian shelf, SW Bay of Bengal: implications on weathering, transport and depositional environment
}

\author{
K Tabita Symphonia ${ }^{1,2, *}$ and D Senthil Nathan ${ }^{1}$ \\ ${ }^{1}$ Department of Earth Sciences, Pondicherry University, Puducherry 605014, India. \\ ${ }^{2}$ Department of Earth Sciences, Eritrea Institute of Technology, Asmara 12676, Eritrea. \\ *Corresponding author. e-mail: tsymphonia@gmail.com
}

MS received 5 October 2017; revised 31 January 2018; accepted 4 February 2018; published online 22 August 2018

Forty-two substrate sediment samples and three cores procured from the shelf region between Chennai and Cuddalore were analyzed to understand the spatial and vertical sediment distribution. Samples subjected to grain size, bulk and clay mineralogical analyses, REE and trace element geochemistry yielded interesting results about the sediment characteristics with respect to the modern day environment. The present study revealed that the study area is characterized by high energy environment marked by predominant composition of medium sand. Results confirmed the evidence of more illite than kaolinite, smectite, and chlorite in the clay mineral assemblage indicating a terrigenous source. Geochemical data also revealed that the enrichment of light rare earth elements (LREE) in the sediments is due to continental source of Precambrian times. High feldspar content in the sediments which is emphasized by bulk mineralogical data displayed positive Eu anomaly. By using the paleoredox index, the area of interest is considered to have undergone no major changes in its depositional settings.

Keywords. Shelf sediments; grain size distribution; clay minerals; geochemistry; Chennai-Cuddalore.

\section{Introduction}

Continental shelf, a transitional zone that lies in between the continent and the deep oceanic basins is a huge depositional complex. The distribution pattern of sediments as observed in the shelves is almost irregular owing to the highly variable sediment characteristics. The detrital sediments in the Bay of Bengal is mostly supplied by the peninsular (Mahanadi, Godavari and Krishna) and extra-peninsular rivers (Ganges and Brahmaputra) that drain into the bay eventually. The Ganges and Brahmaputra rivers derive their sediments from the Himalayas, whereas the peninsular rivers derive their sediment load mainly from the Deccan traps that cover an area of $3 \times 105 \mathrm{~km}^{2}$ in the Indian peninsula (Goldberg and Griffin 1970). Thus the estimated amount of suspended sediments in the bay is nearly 1350 million tons/year (Subramanian et al. 1985; Milliman 2001). The sediments supplied to continental shelf through riverine input, erosion of coasts or the accumulation of biogenic matter are largely controlled by various environmental factors. However, the geological setup prevailing in the shelf region modifies the depositional history of the sediments. Therefore, it is necessary to analyze the grain size data which is considered as the most fundamental tool to study in detail the depositional history of an area (e.g., Folk and Ward 1957) keeping in view the geology of that particular area. The sediment distribution analysis also helps to understand the mode 
of transportation of sediments (Mason and Folk 1958; Friedman 1961, 1967, 1979; Passega 1964; Visher 1969). Textural parameters namely mean, sorting, skewness and kurtosis aid in deducing the depositional phase and the environment that would have prevailed during the time of deposition of sediments (Folk and Ward 1957; Mason and Folk 1958; Friedman 1961, 1967, 1979). The analysis of Rare Earth Elements (REE) in marine sediments serve as powerful indicators of anthropogenic pollution (Borrego et al. 2004), bio-geochemical reactions (Oliveri et al. 2010), provenance studies (Taylor and McLennan 1985), to understand the sediment pathways and decipher the factors controlling dispersion of trace elements (Piper 1974; Toyoda et al. 1990; Murray et al. 1991; Piper et al. 2007; Censi et al. 2010).

\section{Study area}

The east coast is a wave-dominated zone and has a coastline of 2,493 km which experiences storm surges due to cyclones generated in the Bay. Much of the sediment input is contributed by major rivers such as the Ganges, Brahmaputra, Mahanadi, Godavari, Krishna and Cauvery and lesser input is from minor rivers such as Gingee, Palar, Ponnaiyar and Gadilam. The area chosen for the present study lies within the following geographic coordinates $11^{\circ} 34.00-11^{\circ} 42.00 \mathrm{~N}$ and $80^{\circ} 15.81-80^{\circ} 00.70 \mathrm{E}$ which is along the east coast of India. This is situated in the southwestern Bay of Bengal bordered by Chennai and Cuddalore in Tamil Nadu. The continental shelf in the area of interest has an average width of $35 \mathrm{~km}$. The shelf is relatively broader in the northern side and narrows down in the south. The shelf region off Chennai is wide $(50 \mathrm{~km})$ with a gentle gradient whereas it is narrow (only $25 \mathrm{~km}$ wide) and has a steep slope between Pondicherry and Cuddalore (Udayaganesan et al. 2011). The Cuddalore shelf is concave shaped and narrow with an average width of $79 \mathrm{~km}$ and a gentle gradient up to $3000 \mathrm{~m}$ of water depth (Murthy et al. 2006). The shelf breaks on an average of $90-120 \mathrm{~m}$ of water depth (Rana et al. 2007). The continental slope occurs at a depth of $3000 \mathrm{~m}$ in the southern part of the bay as compared to its occurrence at $<2000 \mathrm{~m}$ in the further north owing to relatively less sediment input from the southern rivers.

Therefore, the present study is carried out (i) to know the sediment distribution pattern in the surface and core sediments from the study area, (ii) to understand their mineralogical composition, (iii) to comprehend the REE and trace element distribution in the sediments, and (iv) to trace the source of these sediments using the above results.

\section{Material and methods}

Surface sediment samples were collected along eight transects spanning the shelf region between Chennai and Cuddalore and core samples were obtained from the offshore side of Chennai, Edierthittu and Cuddalore (figure 1). The substrate samples were collected from different depths ranging from $\sim 10$ to $\sim 300 \mathrm{~m}$ depth of water column using van Veen grab sampler during RV Sagar Paschimi cruise. Three core samples were procured using a gravity corer from ORV Sagar Manjusha where a $35 \mathrm{~cm}$ long core was collected off Chennai (C1) from $40 \mathrm{~m}$ of water depth. Second core (C2) measuring $60 \mathrm{~cm}$ was taken from $60 \mathrm{~m}$ depth off Edierthittu and another core (C3) of a length of $36 \mathrm{~cm}$ was taken from off Cuddalore around water depth of $12.5 \mathrm{~m}$. The geographic co-ordinates of the sample sites along with the depth of collection of surface sediments and the core samples are as given in table 1.

\subsection{Grain-size analysis}

Approximately, $500 \mathrm{~g}$ of sediment collected wherever possible was air-dried and oven-dried following which $100 \mathrm{~g}$ of homogenized sample was obtained using coning and quartering method (Tyler 1967). In the case of core samples, subsamples of the same quantity were taken from every $5 \mathrm{~cm}$ interval of the core section. For grain size analysis, samples were pretreated with $\mathrm{H}_{2} \mathrm{O}_{2}$ to remove organic matter and sodium hexametaphosphate was used as a dispersing agent to deflocculate the sediments. Sieving technique was used for samples with abundant coarser $(>63 \mu \mathrm{m})$ fraction and pipette method for samples with sufficient $(<63 \mu \mathrm{m})$ fraction.

\subsubsection{Sieve method}

One hundred grams of each sample was then placed in a stack of ASTM sieves with $1 / 2 \Phi$ (phi) interval $(2.0 \mathrm{~mm}=1 \Phi, 1.0 \mathrm{~mm}=0 \Phi, 0.5 \mathrm{~mm}=1 \Phi$, $0.25 \mathrm{~mm}=2 \Phi, 0.125 \mathrm{~mm}=3 \Phi$ and $0.63 \mathrm{~mm}=$ $4 \Phi)$ and shaken for $10 \mathrm{~min}$. The raw weight of each fraction was noted and expressed as its weight 


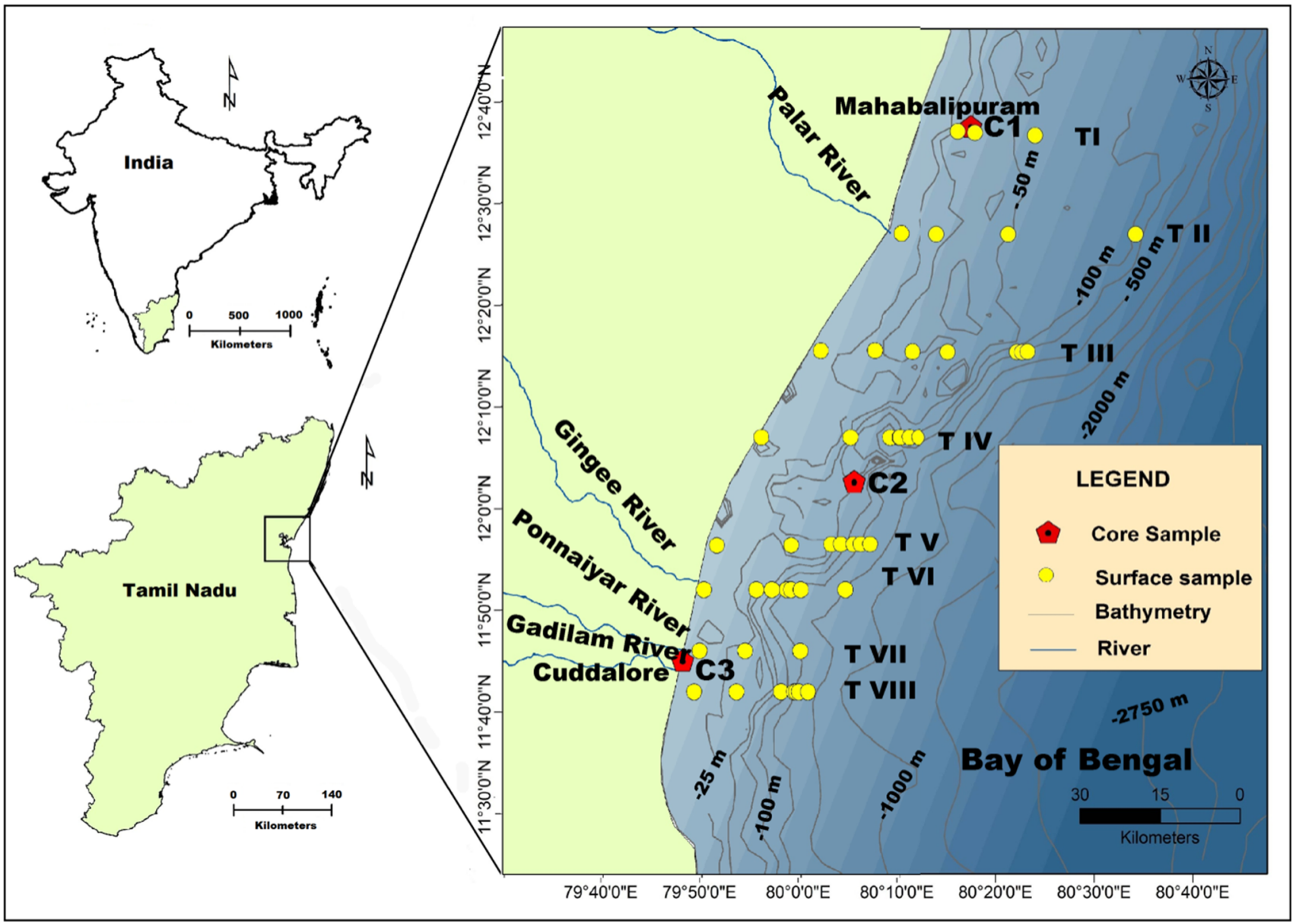

Figure 1. Sample sites in transects I-VIII and core locations C1-C3.

percentage. The gravel, sand and mud content were known using the Udden-Wentworth scale for grain size analysis. However, textural class was assigned based on the mud content after Reineck and Siefert (1980) and Pejrup (1988), modified by Flemming (2000).

\subsubsection{Pipette method}

The finer fraction $(<4 \Phi)$ was determined by the pipette method (Carver 1971). The sample collected in the pan was made up to $1000 \mathrm{ml}$ in the measuring jars and stirred gently for few seconds. Twenty millilitre of the makeup solution was drawn at an interval of $20 \mathrm{~s}$ from the $20 \mathrm{~cm}$ depth which gives the coarse and fine silt + clay reading. Again $20 \mathrm{ml}$ was drawn from another depth of $10 \mathrm{~cm}$ after an interval of $1 \mathrm{~min}$ and $45 \mathrm{~s}$, for fine silt + clay content. Twenty millilitre was drawn for the third time at $3 \mathrm{hr}$ and $10 \mathrm{~min}$ from $5 \mathrm{~cm}$ depth for clay.

\subsection{Mineralogy}

\subsubsection{Bulk mineralogy}

A few selected samples were subjected to bulk mineralogical studies. Samples were crushed in FRITSCH Pulverisette 7Agate Ball mill at $450 \mathrm{rpm}$ for $20 \mathrm{~min}$ in one cycle and were repeated till all the samples were crushed into fine powder.

\subsubsection{Clay mineralogy}

Clay mineralogical studies were attempted by pipetting out $20 \mathrm{ml}$ of solution from $5 \mathrm{~cm}$ depth of a $1000 \mathrm{ml}$ measuring jar in standard intervals of time for settling of clay. This was repeated several times till sufficient aliquots of clay were obtained. Then the solution was centrifuged in R-8C BL centrifuge machine for $25 \mathrm{~min}$ at $3500 \mathrm{rpm}$ until clear supernatant liquid is obtained. The clay collected at the bottom of the centrifuge tubes is retrieved carefully and was finally mounted on glass slides for further analysis in X-ray diffractometer. 
Table 1. Geographic co-ordinates of sample locations and depth in metres.

\begin{tabular}{|c|c|c|c|c|}
\hline Transects/sample sites & Sample id & Depth $(\mathrm{m})$ & Latitude & Longitude \\
\hline \multirow[t]{3}{*}{ I-Off Mahabalipuram } & $\mathrm{S} 1$ & 20 & $11^{\circ} 34.00 \mathrm{~N}$ & $80^{\circ} 15.81 \mathrm{E}$ \\
\hline & $\mathrm{S} 2$ & 32 & $11^{\circ} 34.00 \mathrm{~N}$ & $80^{\circ} 25.50 \mathrm{E}$ \\
\hline & $\mathrm{S} 3$ & 63 & $11^{\circ} 34.00 \mathrm{~N}$ & $80^{\circ} 34.89 \mathrm{E}$ \\
\hline \multirow[t]{4}{*}{ II-Off Palar river } & $\mathrm{S} 4$ & 8 & $12^{\circ} 27.00 \mathrm{~N}$ & $80^{\circ} 10.20 \mathrm{E}$ \\
\hline & $\mathrm{S} 5$ & 21 & $12^{\circ} 27.00 \mathrm{~N}$ & $80^{\circ} 14.00 \mathrm{E}$ \\
\hline & S6 & 35 & $12^{\circ} 27.00 \mathrm{~N}$ & $80^{\circ} 21.30 \mathrm{E}$ \\
\hline & $\mathrm{S} 7$ & 63 & $12^{\circ} 27.00 \mathrm{~N}$ & $80^{\circ} 34.20 \mathrm{E}$ \\
\hline \multirow[t]{6}{*}{ III-Off Edierthittu } & S9 & 28 & $12^{\circ} 15.50 \mathrm{~N}$ & $80^{\circ} 07.50 \mathrm{E}$ \\
\hline & $\mathrm{S} 10$ & 46 & $12^{\circ} 15.40 \mathrm{~N}$ & $80^{\circ} 11.30 \mathrm{E}$ \\
\hline & $\mathrm{S} 11$ & 71 & $12^{\circ} 15.40 \mathrm{~N}$ & $80^{\circ} 15.16 \mathrm{E}$ \\
\hline & $\mathrm{S} 12$ & 86 & $12^{\circ} 15.40 \mathrm{~N}$ & $80^{\circ} 22.20 \mathrm{E}$ \\
\hline & $\mathrm{S} 13$ & 156 & $12^{\circ} 15.40 \mathrm{~N}$ & $80^{\circ} 22.70 \mathrm{E}$ \\
\hline & S14 & 205 & $12^{\circ} 15.44 \mathrm{~N}$ & $80^{\circ} 23.24 \mathrm{E}$ \\
\hline \multirow[t]{7}{*}{ IV-Off Kazhikuppam } & $\mathrm{S} 15$ & 6 & $12^{\circ} 07.00 \mathrm{~N}$ & $79^{\circ} 56.00 \mathrm{E}$ \\
\hline & S16 & 25 & $12^{\circ} 07.00 \mathrm{~N}$ & $80^{\circ} 05.03 \mathrm{E}$ \\
\hline & $\mathrm{S} 17$ & 53 & $12^{\circ} 07.00 \mathrm{~N}$ & $80^{\circ} 09.05 \mathrm{E}$ \\
\hline & S18 & 79 & $12^{\circ} 07.00 \mathrm{~N}$ & $80^{\circ} 10.00 \mathrm{E}$ \\
\hline & S19 & 100 & $12^{\circ} 07.00 \mathrm{~N}$ & $80^{\circ} 10.05 \mathrm{E}$ \\
\hline & $\mathrm{S} 20$ & 167 & $12^{\circ} 07.00 \mathrm{~N}$ & $80^{\circ} 11.00 \mathrm{E}$ \\
\hline & $\mathrm{S} 21$ & 176 & $12^{\circ} 07.00 \mathrm{~N}$ & $80^{\circ} 12.00 \mathrm{E}$ \\
\hline \multirow[t]{7}{*}{ V-Off Muthialpet } & $\mathrm{S} 22$ & 9 & $11^{\circ} 56.40 \mathrm{~N}$ & $79^{\circ} 51.50 \mathrm{E}$ \\
\hline & $\mathrm{S} 23$ & 26 & $11^{\circ} 56.41 \mathrm{~N}$ & $79^{\circ} 59.01 \mathrm{E}$ \\
\hline & $\mathrm{S} 24$ & 51 & $11^{\circ} 56.50 \mathrm{~N}$ & $80^{\circ} 03.05 \mathrm{E}$ \\
\hline & $\mathrm{S} 25$ & 91 & $11^{\circ} 56.50 \mathrm{~N}$ & $80^{\circ} 04.05 \mathrm{E}$ \\
\hline & $\mathrm{S} 26$ & 138 & $11^{\circ} 56.50 \mathrm{~N}$ & $80^{\circ} 05.30 \mathrm{E}$ \\
\hline & $\mathrm{S} 27$ & 176 & $11^{\circ} 56.50 \mathrm{~N}$ & $80^{\circ} 06.05 \mathrm{E}$ \\
\hline & $\mathrm{S} 28$ & 308 & $11^{\circ} 56.50 \mathrm{~N}$ & $80^{\circ} 07.00 \mathrm{E}$ \\
\hline \multirow[t]{6}{*}{ VI-Off Gingee river } & $\mathrm{S} 29$ & 8 & $11^{\circ} 52.00 \mathrm{~N}$ & $79^{\circ} 50.20 \mathrm{E}$ \\
\hline & S30 & 25 & $11^{\circ} 52.00 \mathrm{~N}$ & $79^{\circ} 55.50 \mathrm{E}$ \\
\hline & S31 & 45 & $11^{\circ} 52.00 \mathrm{~N}$ & $79^{\circ} 57.07 \mathrm{E}$ \\
\hline & S32 & 95 & $11^{\circ} 52.00 \mathrm{~N}$ & $79^{\circ} 58.60 \mathrm{E}$ \\
\hline & $\mathrm{S} 33$ & 130 & $11^{\circ} 52.00 \mathrm{~N}$ & $79^{\circ} 59.00 \mathrm{E}$ \\
\hline & S34 & 149 & $11^{\circ} 52.00 \mathrm{~N}$ & $80^{\circ} 00.00 \mathrm{E}$ \\
\hline \multirow[t]{3}{*}{ VII-Off Ponnaiyar river } & S36 & 11 & $11^{\circ} 46.00 \mathrm{~N}$ & $79^{\circ} 49.74 \mathrm{E}$ \\
\hline & S37 & 32 & $11^{\circ} 46.00 \mathrm{~N}$ & $79^{\circ} 54.35 \mathrm{E}$ \\
\hline & S38 & 74 & $11^{\circ} 46.00 \mathrm{~N}$ & $79^{\circ} 59.95 \mathrm{E}$ \\
\hline \multirow[t]{6}{*}{ VIII-Off Cuddalore } & S39 & 9 & $11^{\circ} 42.00 \mathrm{~N}$ & $79^{\circ} 49.20 \mathrm{E}$ \\
\hline & S40 & 15 & $11^{\circ} 42.00 \mathrm{~N}$ & $79^{\circ} 53.50 \mathrm{E}$ \\
\hline & $\mathrm{S} 41$ & 26 & $11^{\circ} 42.00 \mathrm{~N}$ & $79^{\circ} 58.00 \mathrm{E}$ \\
\hline & S43 & 119 & $11^{\circ} 42.00 \mathrm{~N}$ & $79^{\circ} 59.50 \mathrm{E}$ \\
\hline & $\mathrm{S} 44$ & 161 & $11^{\circ} 42.00 \mathrm{~N}$ & $79^{\circ} 59.80 \mathrm{E}$ \\
\hline & $\mathrm{S} 45$ & 282 & $11^{\circ} 42.00 \mathrm{~N}$ & $80^{\circ} 00.70 \mathrm{E}$ \\
\hline
\end{tabular}

\subsubsection{Mineralogical analyses by XRD}

Each powdered sample to be analyzed for its bulk mineralogical composition was loaded in a sample holder and was scanned from 10 to $75^{\circ} 2 \theta$ in PANalytical X'Pert Pro ${ }^{\mathrm{TM}}$ X-ray diffractometer with a copper target (CuK $\alpha$ radiation). For clay mineral identification, X-Ray analysis was carried out such that (i) untreated, (ii) glycol-treated, and (iii) heat-treated patterns were obtained for each sample. Untreated clay analysis was done by smearing the clay on to a glass slide and then scanned at room temperature. Two different aliquots of clay were saturated with $\mathrm{Ca}$ and $\mathrm{K}$ prior to glycolation and heat treatment following the ion saturation procedure of Brown and Brindley (1980). Ca-saturated glass slides were subjected to glycol treatment by exposing them to $250 \mathrm{ml}$ of ethylene 
glycol in the desiccator (Brunton 1955) and kept in an oven at $60^{\circ} \mathrm{C}$ for $4 \mathrm{hr}$ for semi-quantification of samples containing smectite. To obtain diffractometer patterns by heat treatment, K-saturated clay slides were kept in a furnace at $550^{\circ} \mathrm{C}$ for $4-$ $5 \mathrm{hr}$ and run in XRD. Each sample was scanned using a continuous scan mode from 2 to $40^{\circ} 2 \theta$ for $60 \mathrm{~min}$ with a scan speed of $0.6^{\circ} 2 \theta / \mathrm{min}$ at $40 \mathrm{kV}$ and $25 \mathrm{~mA}$. The data thus measured was compared with the reference database (ICDD) in PANalytical X'Pert High Score v.2.0a (2.0.1) and phase identification was determined as a result.

\subsection{REE and trace element study by Quadrupole $I C P-M S$}

Seven millilitre Savillex ${ }^{\circledR}$ Teflon vials used for digesting the samples, TARSON bottles and scintillation vials used to store the stock and diluted solution of the digested samples were thoroughly washed many times with milliQ and dried. $0.01 \mathrm{~g}$ of sample was weighed and taken in Savillex Teflon pressure decomposition vessels. The samples were pre-treated with 1:1 $\mathrm{H}_{2} \mathrm{O}_{2}$ solution following which $2 \mathrm{ml}$ of concentrated $\mathrm{HNO}_{3}$ and $3-4 \mathrm{ml}$ of an acid mixture containing a 7:3:1 ratio of $\mathrm{HF}, \mathrm{HNO}_{3}$ and $\mathrm{HCl}$ were added to the vials. To ensure the removal of fluoride complexes and to obtain a clear solution, 2-3 $\mathrm{ml}$ of concentrated $\mathrm{HNO}_{3}$ was added further. The residue was made up to $100 \mathrm{ml}$ clean TARSON bottles in room temperature and the stock solution was stored for analysis. Empty weights and sample+weight of the polyethylene bottles were also recorded. Two millilitre of the stock solution was again made up to $10 \mathrm{ml}$ in clean scintillation vials and then run in Thermo Scientific XSERIES 2 Quadrupole ICP-MS for analysis of trace elements which has a scan speed of $>9000$ microseconds per element. The instrument was calibrated and corrected for isobaric interferences by standardizing using internal and USGS standards (SDC-1 and BCR-2).

\section{Results}

\subsection{Grain-size distribution}

The results are based on the analyses carried out on a suite of 68 samples, i.e., 42 surface sediment samples along with 26 subsamples from three cores (taken from every $5 \mathrm{~cm}$ interval of the core) collected from different depths in the east coast.

\subsubsection{Surface sediments}

Shelf surface sediment distribution is very much affected by physical factors such as waves, tides and currents. Therefore, studying the spatial changes in the textural parameters such as mean, sorting, skewness and kurtosis is the most fundamental and standard way of tracing sediment transport pathways (Balsinha et al. 2014). These parameters were extracted by the method of moments using GRADISTAT, version 8.0 (Blott and Pye 2001) as given in table 2 and distribution maps were constructed using ArcGIS ${ }^{\circledR}$, version.10 (ESRI). The mean values ranged between 0.10 and $3.55 \Phi$ and the average mean value of the surface sediments, $1.45 \Phi$ corresponding to medium sand showed predominant distribution. The coarser mean values are found near the coast while the finer values are slightly away from the coast (figure 2). The standard deviation values of the sediments ranged between moderately well sorted (min. 0.64) to poorly sorted (max. 1.66). More than $50 \%$ of the samples revealed that they are poorly sorted, while $38 \%$ are moderately sorted and $\sim 10 \%$ of them are moderately well sorted. Thus an average value of 1.04 indicates that they are overall poorly sorted. The samples displayed a good range of skewness values with relatively more negatively skewed samples and less number of positively skewed samples. The samples widely varied between platykurtic to very leptokurtic nature. Majority of the samples (41\%) displayed mesokurtic character and $24 \%$ are platykurtic, $17 \%$ are leptokurtic and $19 \%$ are very leptokurtic. Among the surface samples, $76 \%$ are characterized as unimodal and $24 \%$ as bimodal in nature.

\subsubsection{Core sediments}

Three cores analyzed for down core variation of sediment distribution revealed that sand content is higher in C2 (off Edierthittu) and in C3 (off Cuddalore) while higher amount of clay was witnessed in C1 (off Chennai). The silt content encountered in the core sediments was moderate ( $\sim 10$ to $20 \%)$. In Chennai core (C1), major portion $(75 \%)$ of the sediments was clay (table 3 ). The first $5 \mathrm{~cm}$ of the core contained more clay content but it steadily decreased down the core by remaining more or less constant below $10 \mathrm{~cm}$. The remaining bulk of the core was made up by silt and sand where silt content varied between $>12$ and $20 \%$ and sand 


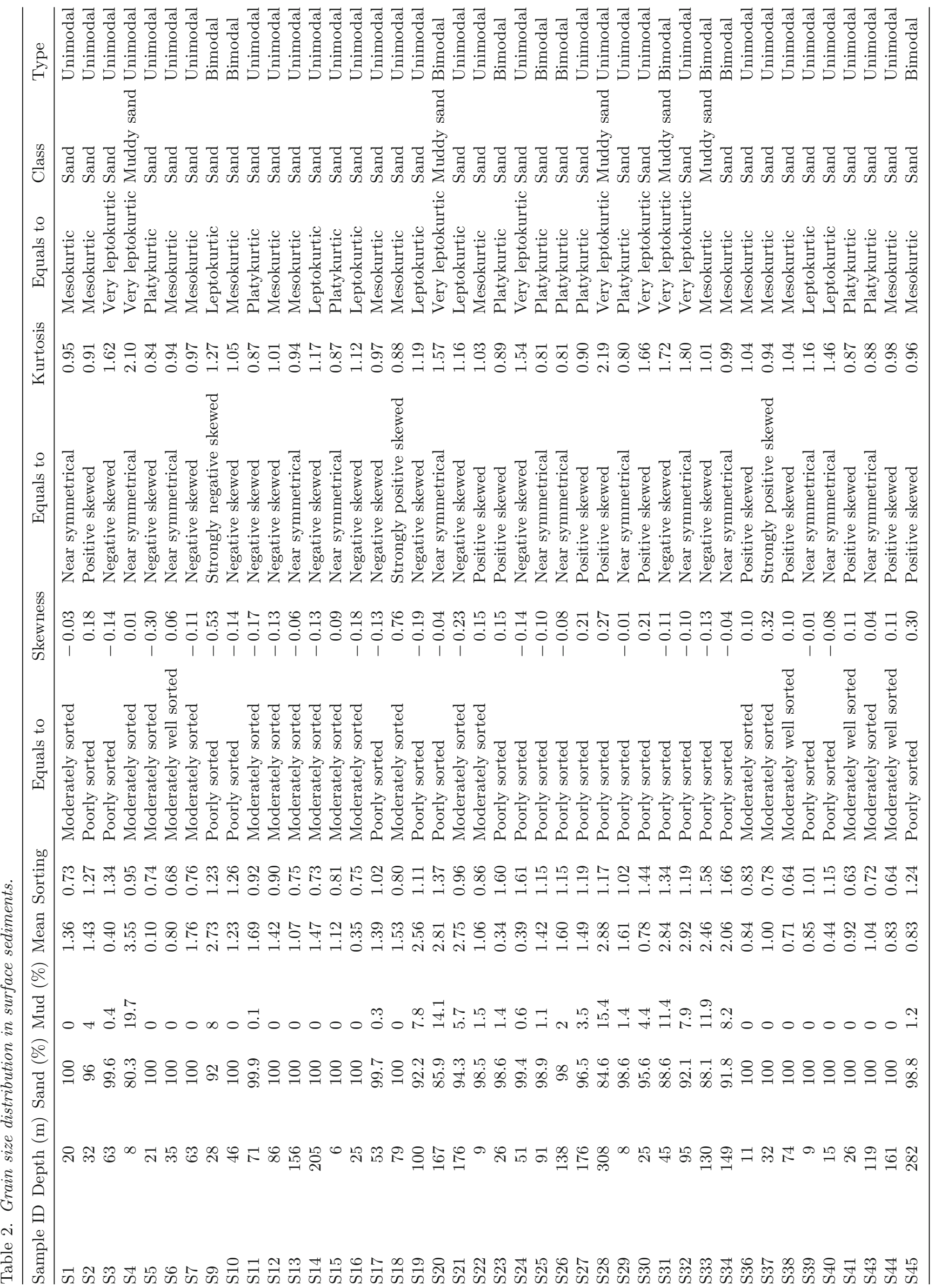


(a)

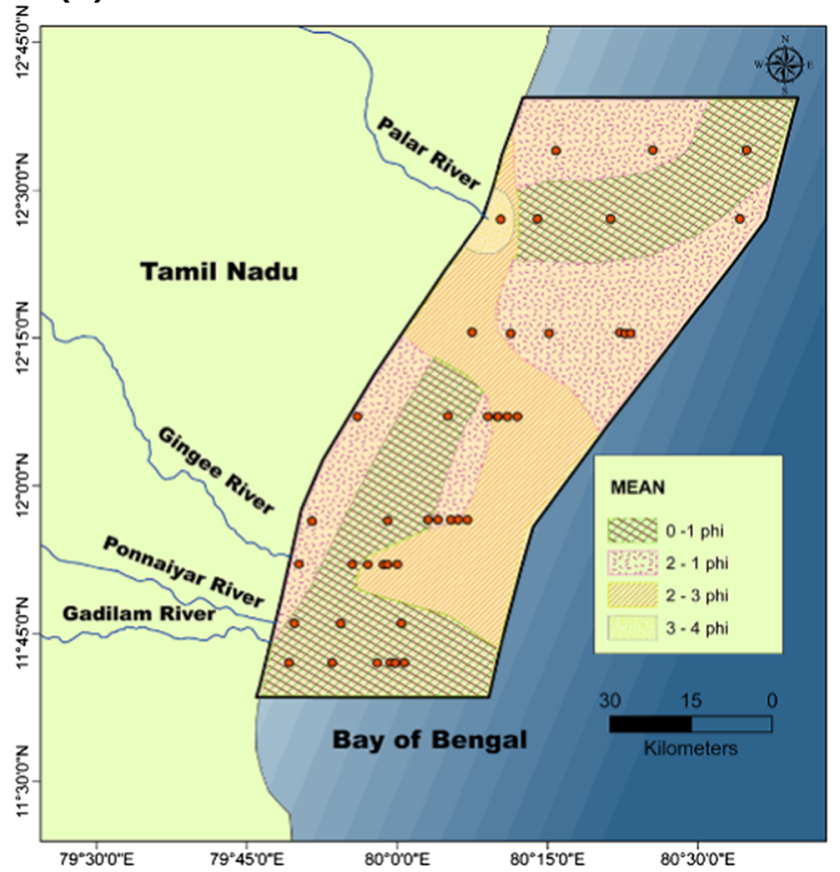

(c)

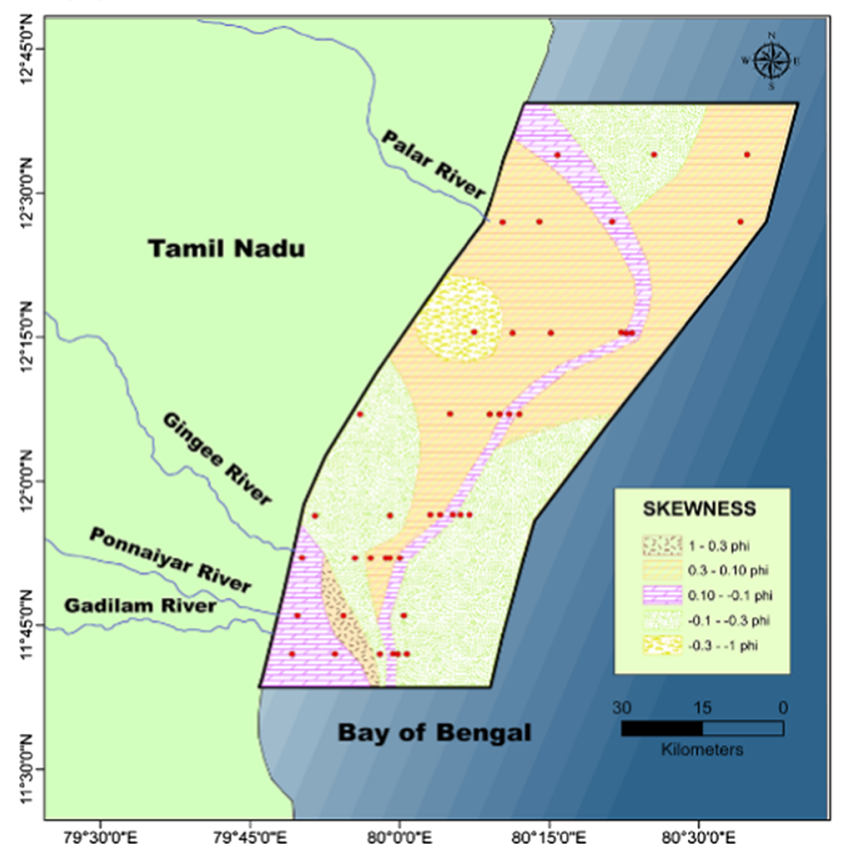

(b)

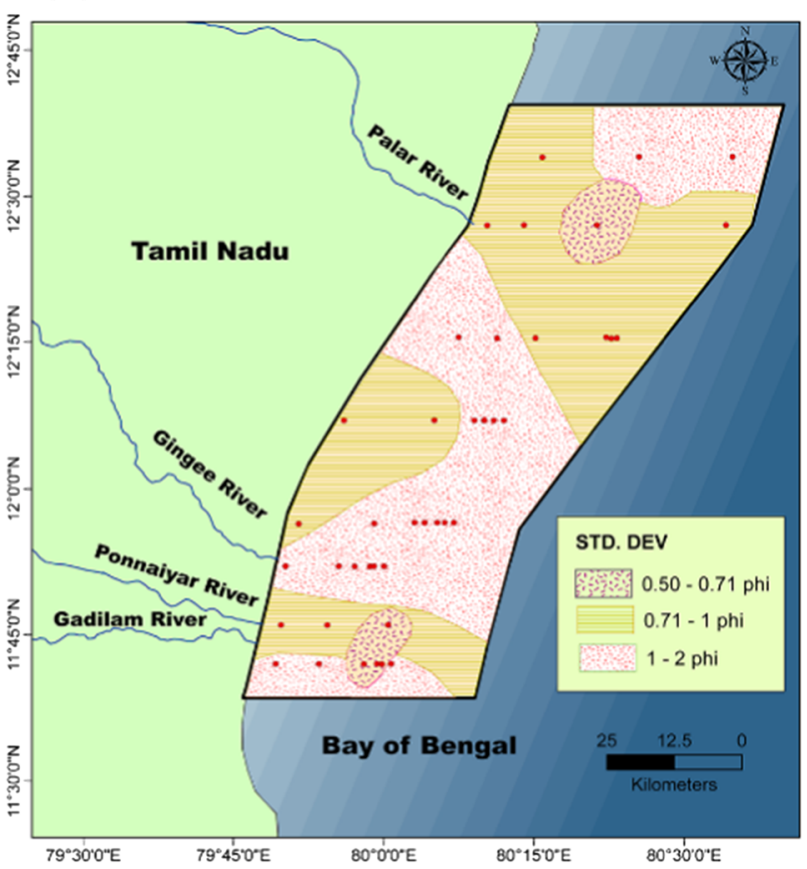

(d)

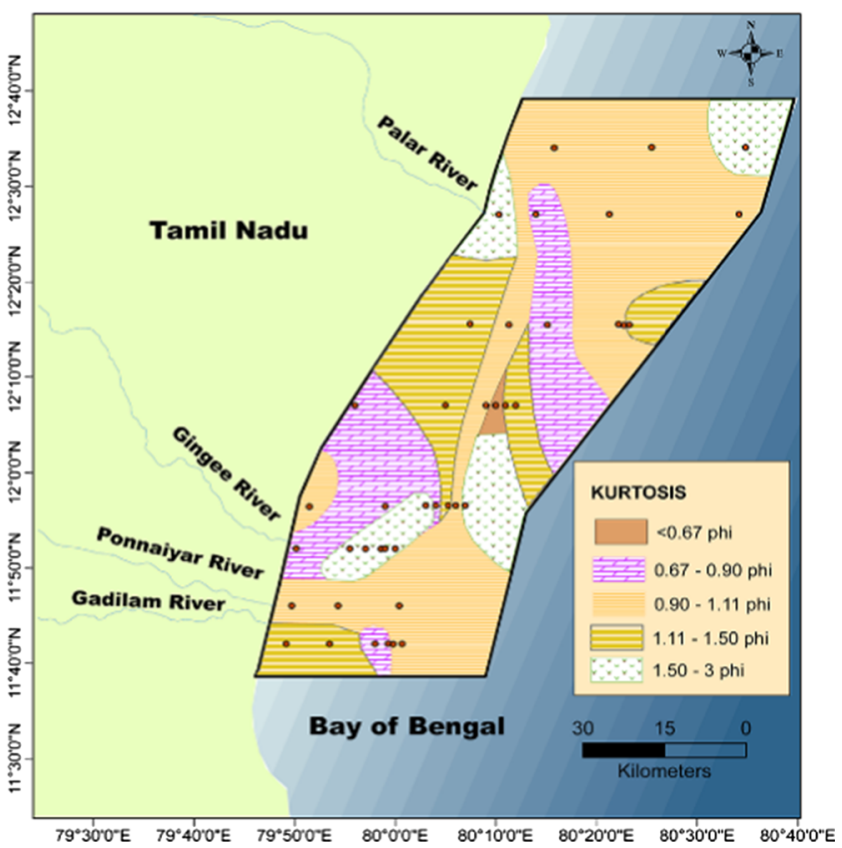

Figure 2. Distribution of textural parameters (a) mean, (b) standard deviation, (c) skewness, and (d) kurtosis of surface sediments.

content ranged between 5 and 10\%. In core (C2), off Edierthittu, sand was the predominant fraction making up an average of $94 \%$ of the sediments in the core and very slight down core variation was observed. Gravel and mud showed an inverse relationship in the entire core constituting the remaining 4 and $3 \%$ of the total sediments respectively. In the third core (C3), collected off Cuddalore, sand and clay content showed an inverse relation while silt content increased gradually in the lower half of the core. Sand made up half $(50 \%)$ of the core sediments while the other half of the core is composed of silt (16.5\%) and clay (33.5\%), respectively (figure 3). 
Table 3. Sediment distribution in cores.

\begin{tabular}{|c|c|c|c|c|c|}
\hline Sample id & $\begin{array}{c}\text { Depth } \\
(\mathrm{cm})\end{array}$ & $\begin{array}{c}\text { Sand } \\
(\%)\end{array}$ & $\begin{array}{l}\text { Silt } \\
(\%)\end{array}$ & $\begin{array}{c}\text { Clay } \\
(\%)\end{array}$ & Class \\
\hline \multicolumn{6}{|c|}{ C1-Off Chennai } \\
\hline $\mathrm{C} 1-1$ & 5 & 5.99 & 12.88 & 81.13 & Slightly sandy mud \\
\hline $\mathrm{C} 1-2$ & 10 & 8.38 & 18.35 & 73.27 & Slightly sandy mud \\
\hline $\mathrm{C} 1-3$ & 15 & 7.3 & 19.09 & 73.62 & Slightly sandy mud \\
\hline $\mathrm{C} 1-4$ & 20 & 7.44 & 18.58 & 73.98 & Slightly sandy mud \\
\hline $\mathrm{C} 1-5$ & 25 & 8.11 & 17.98 & 73.91 & Slightly sandy mud \\
\hline $\mathrm{C} 1-6$ & 30 & 9.87 & 16.41 & 73.72 & Slightly sandy mud \\
\hline $\mathrm{C} 1-7$ & 35 & 9.08 & 16.28 & 74.63 & Slightly sandy mud \\
\hline \multicolumn{6}{|c|}{ C2-Off Edierthittu } \\
\hline $\mathrm{C} 2-1$ & 5 & 0.50 & 94.76 & 4.56 & Sand \\
\hline $\mathrm{C} 2-2$ & 10 & 0.72 & 95.14 & 4.06 & Sand \\
\hline $\mathrm{C} 2-3$ & 15 & 1.98 & 89.31 & 8.71 & Slightly muddy sand \\
\hline $\mathrm{C} 2-4$ & 20 & 8.94 & 89.98 & 1.09 & Sand \\
\hline $\mathrm{C} 2-5$ & 25 & 4.27 & 93.92 & 1.81 & Sand \\
\hline $\mathrm{C} 2-6$ & 30 & 4.99 & 92.62 & 2.39 & Sand \\
\hline $\mathrm{C} 2-7$ & 35 & 3.54 & 96.07 & 0.39 & Sand \\
\hline $\mathrm{C} 2-8$ & 40 & 2.03 & 96.82 & 1.16 & Sand \\
\hline $\mathrm{C} 2-9$ & 45 & 2.71 & 95.87 & 1.42 & Sand \\
\hline $\mathrm{C} 2-10$ & 50 & 2.36 & 96.4 & 1.24 & Sand \\
\hline $\mathrm{C} 2-11$ & 55 & 6.18 & 92.99 & 0.83 & Sand \\
\hline $\mathrm{C} 2-12$ & 61 & 8.05 & 91.38 & 0.57 & Sand \\
\hline \multicolumn{6}{|c|}{ C3-Off Cuddalore } \\
\hline C3-1 & 5 & 83.02 & 10.33 & 14.94 & Muddy sand \\
\hline C3-2 & 10 & 64.51 & 9.05 & 26.42 & Muddy sand \\
\hline C3-3 & 15 & 57.37 & 12.79 & 29.8 & Muddy sand \\
\hline C3-4 & 20 & 38.45 & 17.24 & 39.81 & Sandy mud \\
\hline C3-5 & 25 & 32.57 & 16.83 & 50.59 & Sandy mud \\
\hline C3-6 & 30 & 37.94 & 25.44 & 36.61 & Sandy mud \\
\hline C3-7 & 37 & 39 & 24.12 & 37.36 & Sandy mud \\
\hline
\end{tabular}

\subsection{Mineralogy}

Bulk powder analysis of sediment or rock samples helps in quick mineral identification and also a detailed characterization of clay minerals present in the finer sediment fractions is carried out by XRD. Few selected surface sediment samples and subsamples from C1 (off Chennai) and C3 (off Cuddalore) cores were used for this mineralogical study.

\subsubsection{Bulk mineralogy}

The framework constituents of surface sediments were identified as quartz, plagioclase and orthoclase feldspars and calcite. However, the dominant minerals were quartz, albite, anorthite and calcite. Pyroxenes such as augite, enstatite, diopside and spodumene; sulphides such as chalcopyrite and covellite; micas such as muscovite besides rutile and zircon were present in minor amounts. Clay minerals such as kaolinite, illite and montmorillonite were also found in the sediments.

\subsubsection{Clay mineralogy}

Diffractograms from X-ray analysis revealed the presence of clay minerals such as kaolinite, illite, smectite (montmorillonite), chlorite and a few mixed-layer minerals. The non-clay minerals that were identified include chalcopyrite, sphalerite, lepidolite, microcline, albite, biotite and calcite. The samples showed kaolinite peaks at 12.38 and $24.942 \theta$ with the d-spacing of 7.15 and $3.57 \AA$, respectively. Kaolinite is identified by the disappearance of $7.15 \AA$ reflection on heating above $500^{\circ} \mathrm{C}$. Smectite peak was observed upon glycolation at $52 \theta(17.08 \AA)$. The samples showed 
C1- Off Chennai
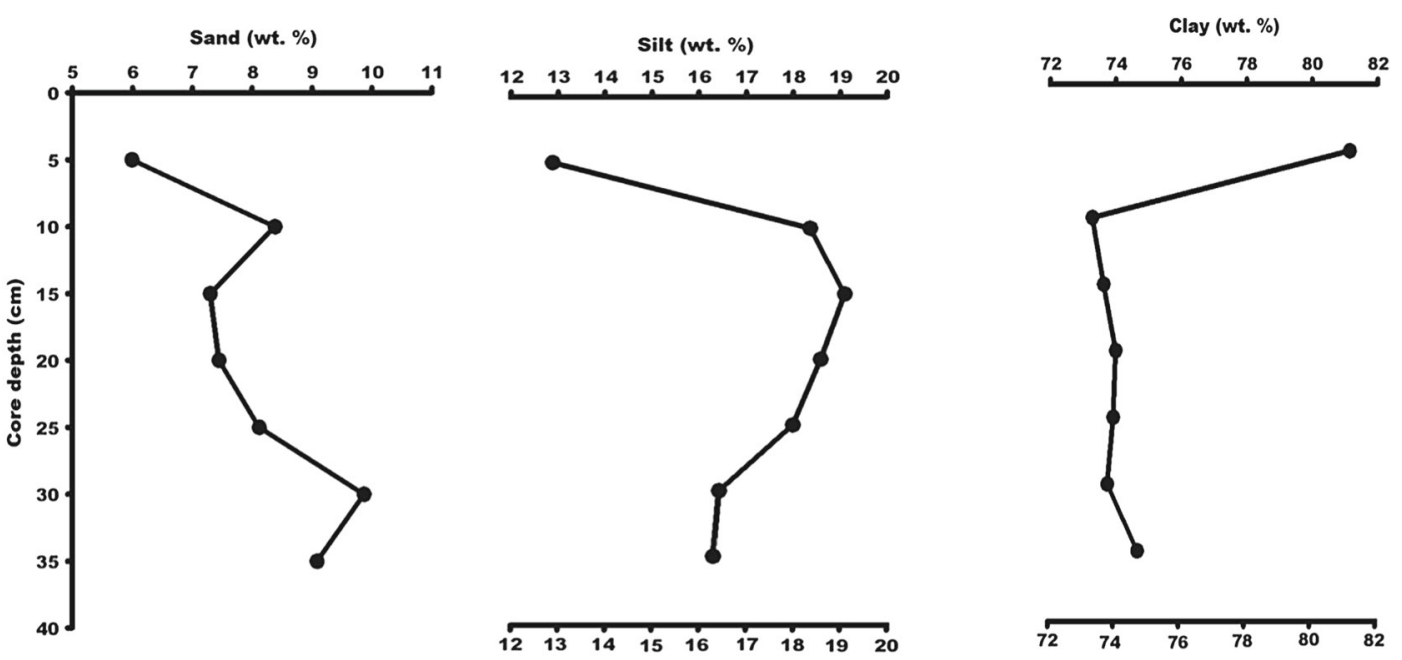

\section{C2- Off Edierthittu}
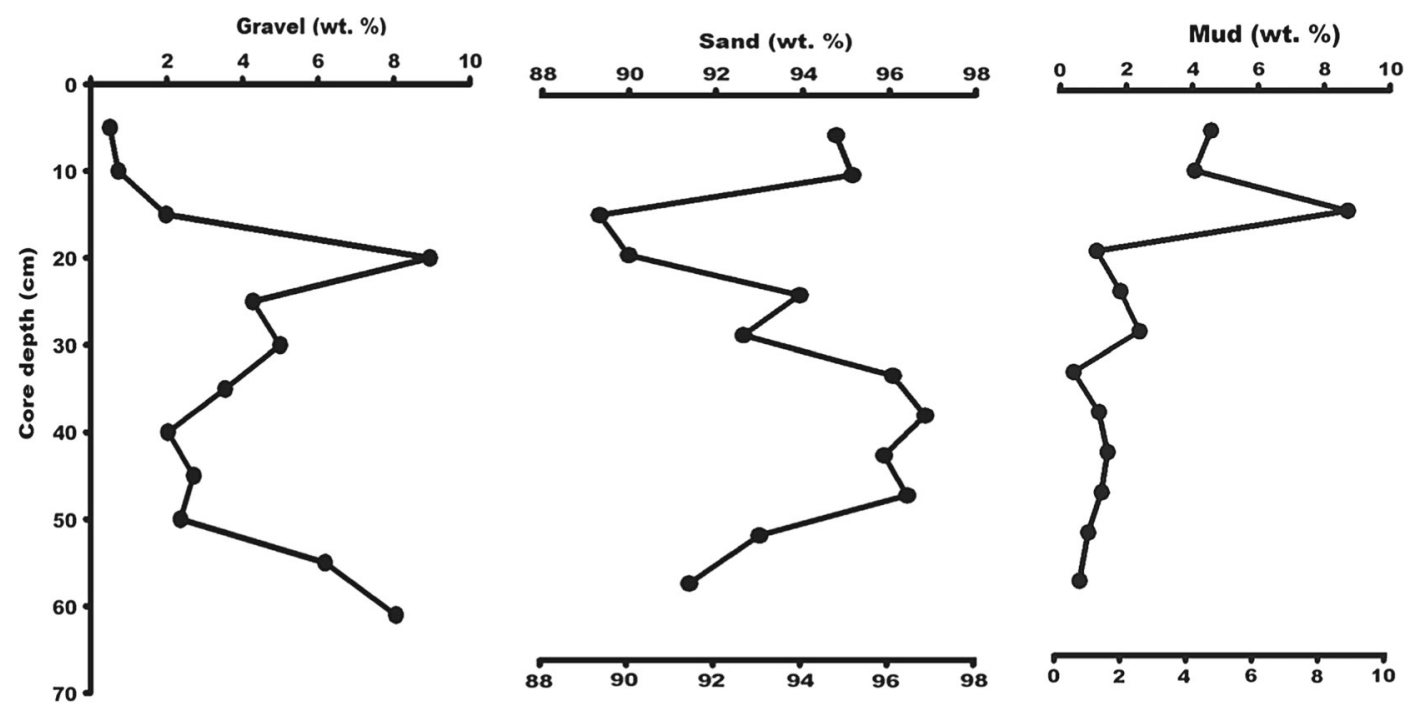

\section{C3- Off Cuddalore}
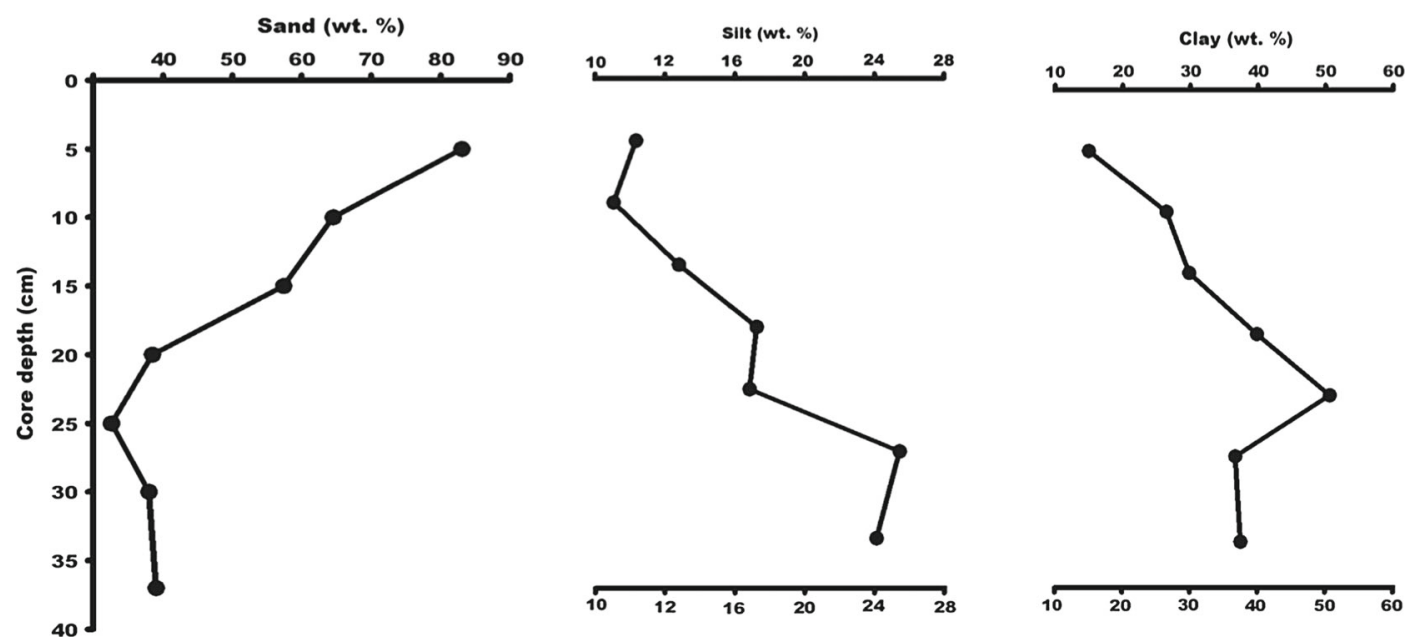

Figure 3. Down core sediment distribution in three cores. 
(a)

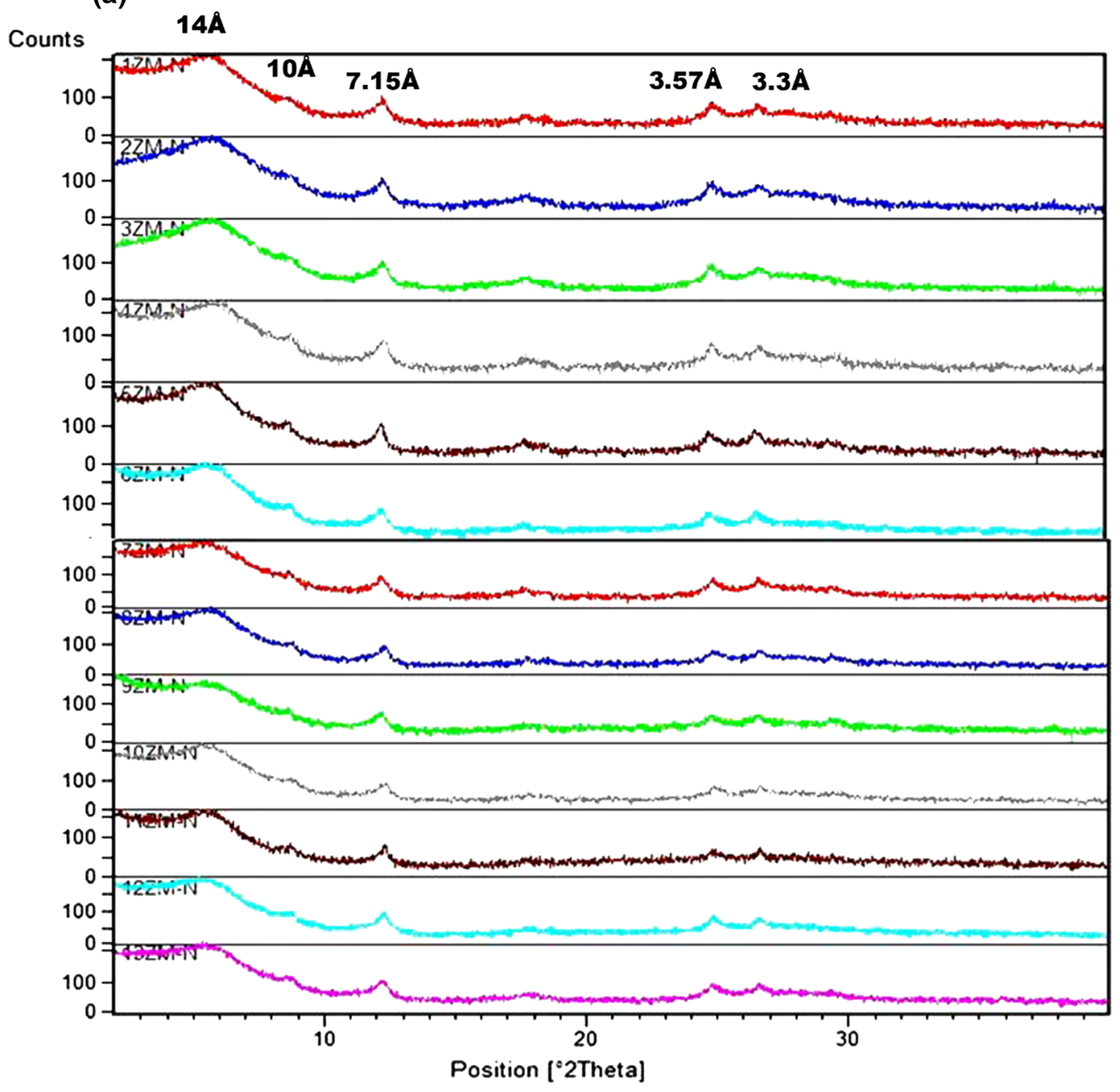

(b)

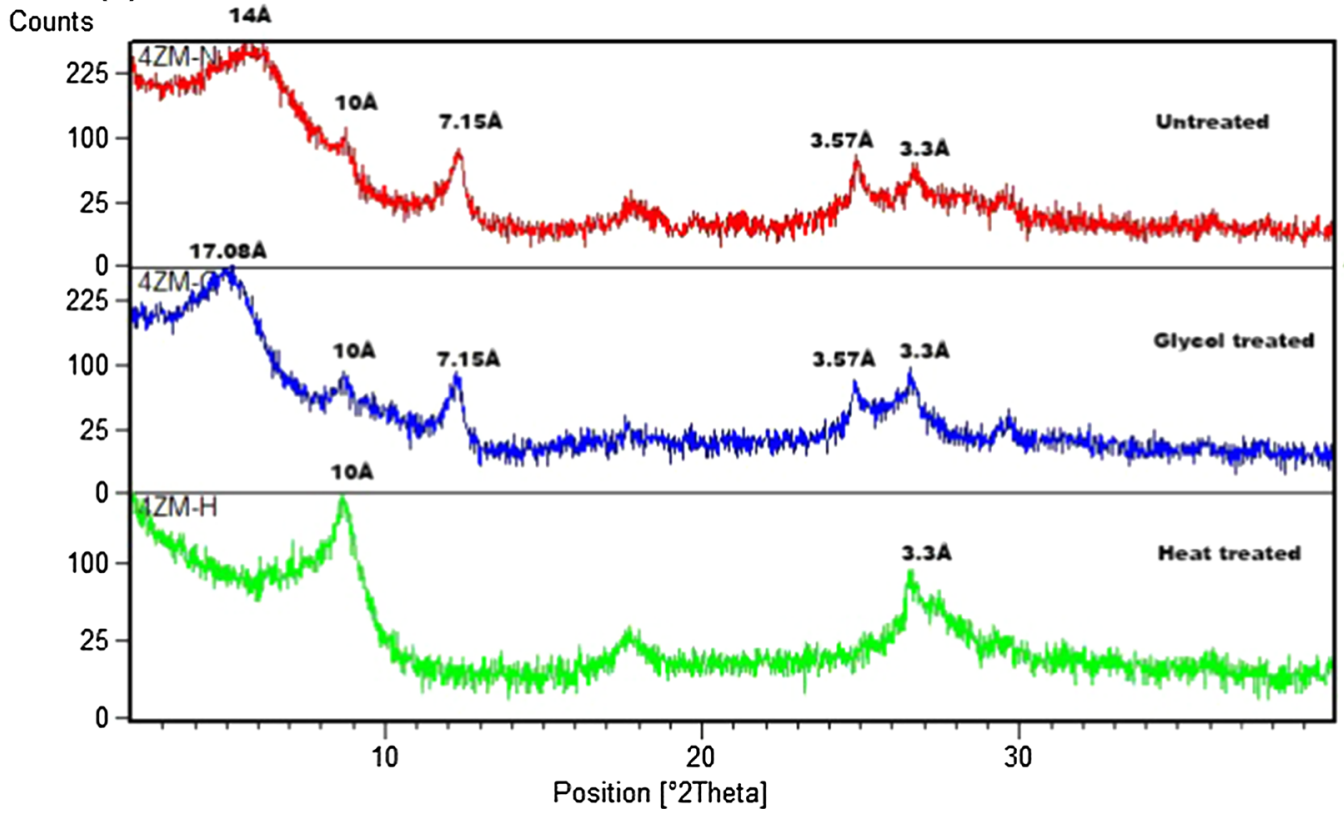

Figure 4. (a) XRD diffractograms of all clay minerals present in surface samples and (b) clay minerals in (i) untreated, (ii) glycol-treated, and (iii) heat-treated slides. 

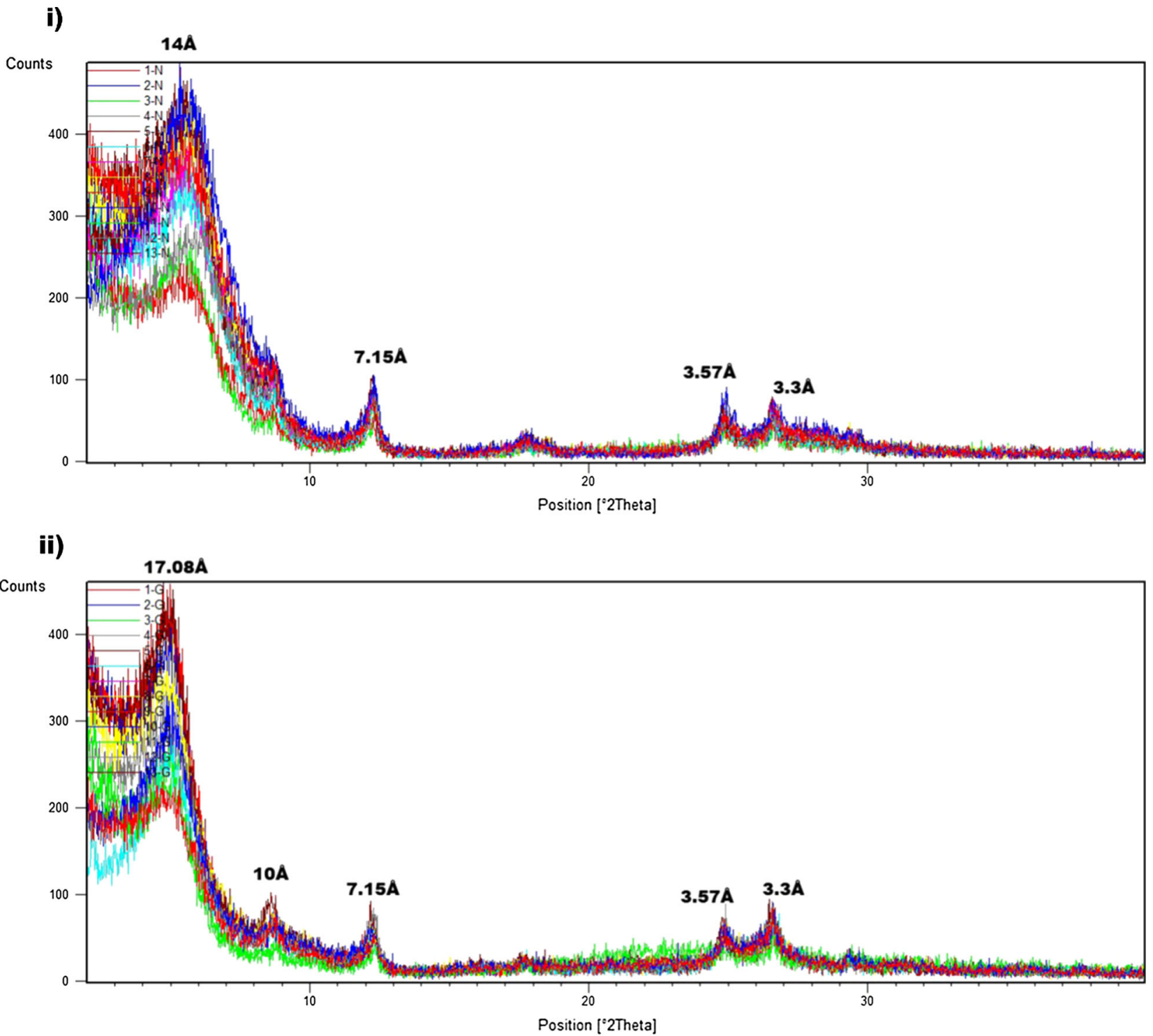

iii)

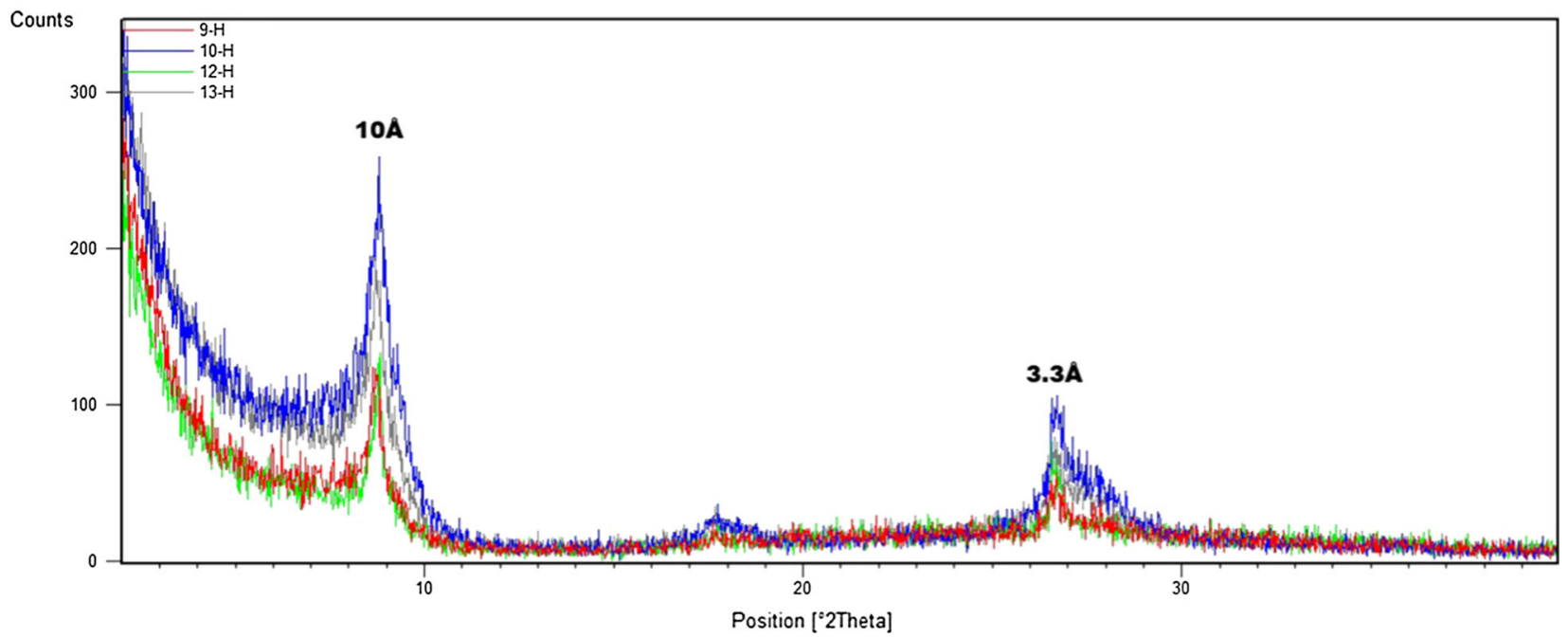

Figure 5. Diffractograms of clay minerals present in core samples C1 (off Chennai) and C3 (off Cuddalore): (i) untreated, (ii) glycol-treated, and (iii) heat-treated slides. 
Table 4. Percentage of clay minerals present in the surface and core samples.

\begin{tabular}{|c|c|c|c|c|c|}
\hline Sample id & Depth (m) & Illite (\%) & Kaolinite (\%) & Smectite (\%) & Chlorite (\%) \\
\hline $\mathrm{S} 4$ & 8 & 13.61 & 16.06 & 62.24 & 8.09 \\
\hline S16 & 25 & 9.38 & 7.91 & 79.51 & 3.20 \\
\hline S17 & 53 & 10.18 & 6.03 & 81.50 & 2.29 \\
\hline S18 & 79 & 11.61 & 7.69 & 78.60 & 2.10 \\
\hline $\mathrm{S} 20$ & 167 & 11.10 & 6.12 & 79.19 & 3.59 \\
\hline $\mathrm{S} 24$ & 51 & 10.00 & 8.34 & 77.13 & 4.53 \\
\hline $\mathrm{S} 25$ & 91 & 12.35 & 9.05 & 75.51 & 3.09 \\
\hline S28 & 308 & 13.12 & 8.76 & 75.14 & 2.98 \\
\hline $\mathrm{S} 29$ & 8 & 12.58 & 11.00 & 71.70 & 4.72 \\
\hline S30 & 25 & 11.90 & 15.79 & 68.00 & 4.31 \\
\hline S31 & 45 & 8.60 & 9.00 & 77.8 & 4.60 \\
\hline S32 & 95 & 13.58 & 14.00 & 68.20 & 4.22 \\
\hline S33 & 130 & 9.80 & 12.70 & 73.00 & 4.50 \\
\hline C1-1 & $0.01-0.05$ & 10.00 & 72.00 & 14.50 & 3.50 \\
\hline C1-2 & $0.06-0.1$ & 11.40 & 70.00 & 16.50 & 2.10 \\
\hline C1-3 & $0.11-0.15$ & 10.15 & 69.20 & 18.05 & 2.60 \\
\hline C1-4 & $0.16-0.2$ & 11.00 & 71.00 & 15.90 & 2.10 \\
\hline C1-5 & $0.21-0.25$ & 11.40 & 70.10 & 16.00 & 2.50 \\
\hline C1-6 & $0.26-0.3$ & 11.00 & 70.50 & 16.25 & 2.25 \\
\hline C3-1 & $0.01-0.05$ & 6.91 & 13.57 & 75.22 & 4.30 \\
\hline C3-2 & $0.06-0.1$ & 7.50 & 25.00 & 65.00 & 2.50 \\
\hline C3-3 & $0.11-0.15$ & 8.15 & 30.00 & 59.00 & 2.85 \\
\hline C3-4 & $0.16-0.2$ & 15.50 & 38.50 & 40.00 & 6.00 \\
\hline C3-5 & $0.21-0.25$ & 20.00 & 51.00 & 25.00 & 4.00 \\
\hline C3-6 & $0.26-0.3$ & 22.50 & 35.00 & 39.00 & 35.00 \\
\hline C3-7 & $0.31-0.32$ & 16.85 & 38.50 & 40.50 & 4.15 \\
\hline
\end{tabular}

prominent peaks at $26.752 \theta(3.3 \AA)$ and $8.82 \theta 10 \AA$ corresponding to illite which is affected neither by glycol nor heat treatment. The peak corresponding to chlorite was observed at $6.32 \theta(14 \AA)$ which is affected by glycolation and by heating due to the presence of vermiculite (Figures 4 and 5). The relative clay mineral abundances in the samples were calculated using Biscaye (1965) method as given in table 4. Surface samples showed predominance of kaolinite followed by illite whereas the dominating clay mineral in the core samples is illite. Inner shelf sandy sediments witnessed higher kaolinite content. The down core clay mineral variation as observed in $\mathrm{C} 1$ exhibited higher amounts of illite than kaolinite, smectite and chlorite. The sandy upper half of C3 showed abundance of kaolinite while the muddy lower half showed decrease in kaolinite and increase in illite content.

\subsection{Trace element studies}

Rare earth elements (REE) and trace elemental study was performed on two cores, C1-off Chennai and C3-off Cuddalore. The average mean values of the REEs in the core sediments are given in table 5 . The average REEs is higher in C3 $(28.74 \pm 2.81)$ than $\mathrm{C} 1(25.84 \pm 4.28)$. The trend of variation in the concentration of REEs showed that Er is greater than $\mathrm{Eu}$ in $\mathrm{C} 1$, while in $\mathrm{C} 3 \mathrm{Eu}$ dominated Er.

Continental shelf has sediments from terrigenous source, of authigenic origin or biogenic nature. Therefore REEs of both the cores were normalized to Post Archaen Australian Shale (PAAS), (McLennan 1989) because PAAS displays a combined effect of all the three types of sediments. The $\Sigma$ REE values of $\mathrm{C} 1$ showed a higher value of $361.8 \mathrm{ppm}$ and $\mathrm{C} 3$ showed a still higher value of $402.4 \mathrm{ppm}$. The patterns corresponding to $\mathrm{C} 1$ and C3 are shown in figure 6. They showed an enrichment of light rare earth elements (LREE) over heavy rare earth elements (HREE) in the core sediments. In order to know the degree of fractionation of LREE and HREE in the sediments, $\mathrm{La}_{\mathrm{n}} / \mathrm{Sm}_{\mathrm{n}}$ and $\mathrm{Gd}_{\mathrm{n}} / \mathrm{Yb}_{\mathrm{n}}$ were calculated. The $\mathrm{La}_{\mathrm{n}} / \mathrm{Sm}_{\mathrm{n}}$ value for $\mathrm{C} 1$ is 1.08 and the corresponding value for $\mathrm{C} 3$ is 0.99. Similarly, the $\mathrm{Gd}_{\mathrm{n}} / \mathrm{Yb}_{\mathrm{n}}$ value for $\mathrm{C} 1$ is 1.93 


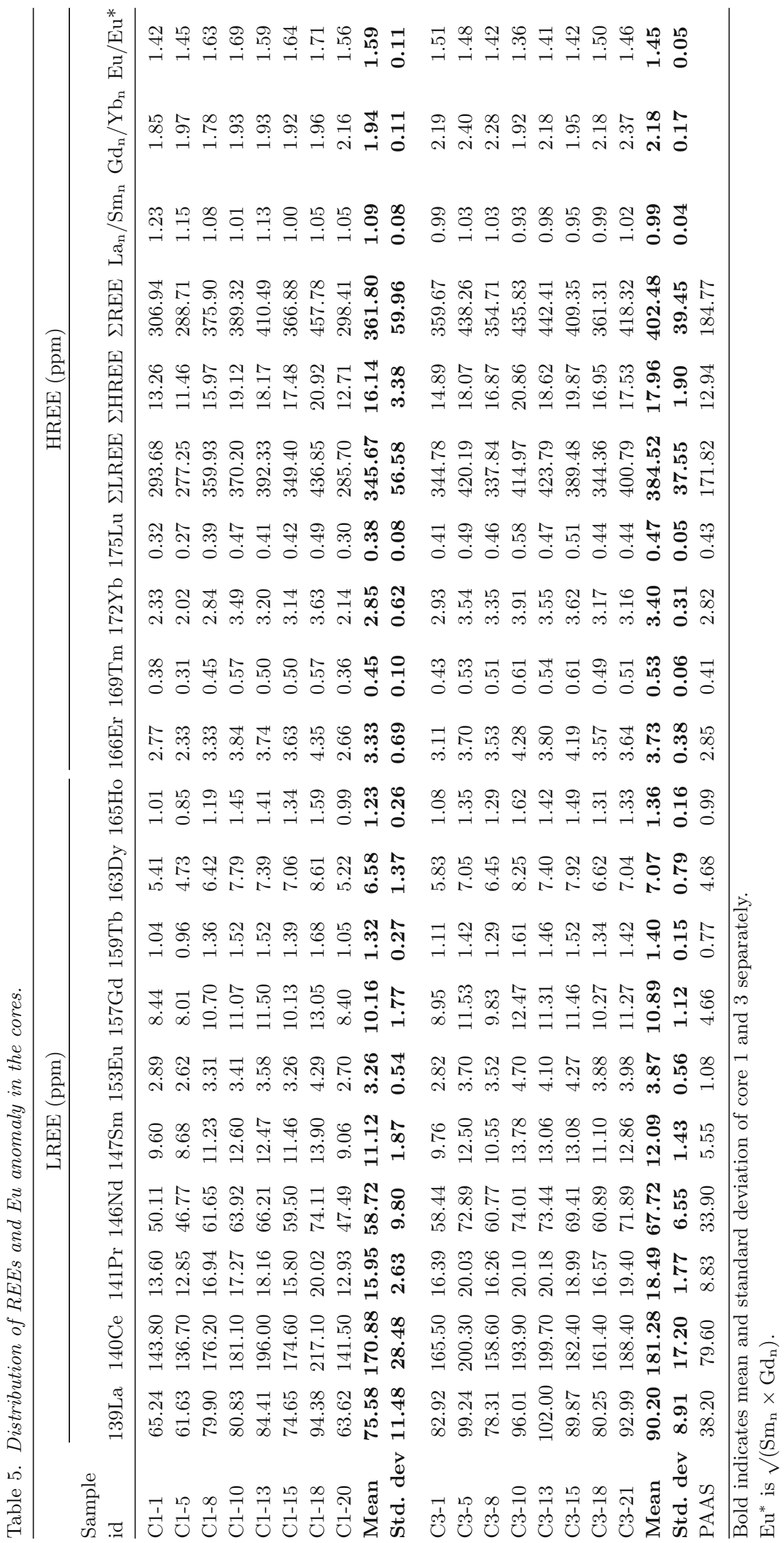



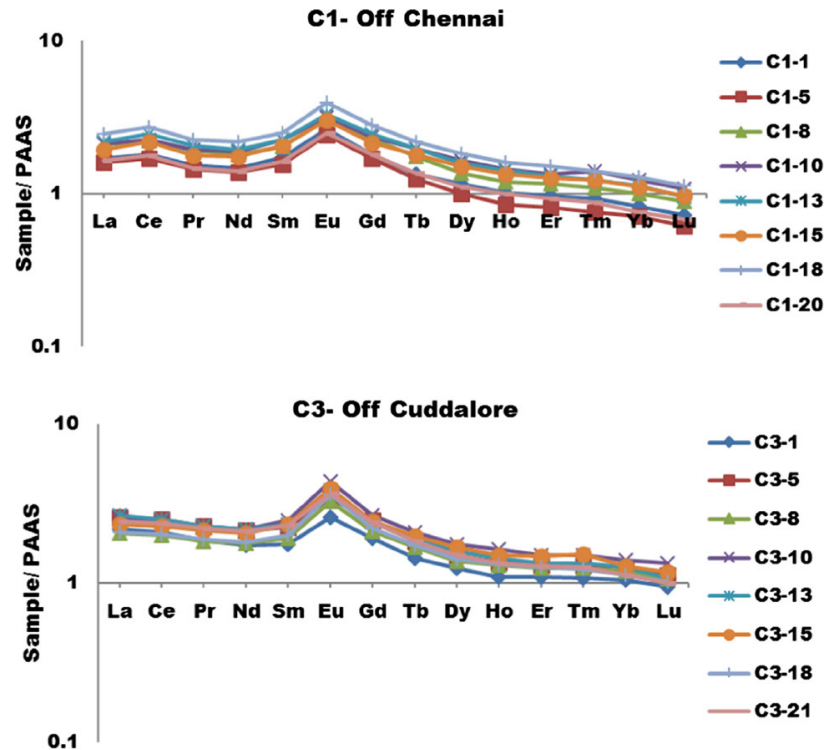

Figure 6. PAAS (McLennan 1989) normalized REE pattern for $\mathrm{C} 1$ and $\mathrm{C} 3$ cores.

and the corresponding value for C3 is 2.18. Positive $\mathrm{Eu}$ anomaly is observed in both the cores (figure 4). The Eu anomaly in $\mathrm{C} 1$ varied between 1.4 and 1.7 and ranged from 1.4 to 1.5 in C3. Trace elements such as vanadium, chromium, cobalt, nickel and zircon showed higher abundances in C1 than in C3 with Mn showing the highest concentration. Other elements such as the radioactive lead, thorium and uranium showed higher concentration in C3 than in $\mathrm{C} 1$ with the highest abundance of zinc in the sediments. The concentrations of these elements are given in table 6 . In order to better understand the depositional conditions of sediments, Paleoredox Index (PI) was calculated using vanadium and chromium concentrations. The values of PI for both $\mathrm{C} 1$ and $\mathrm{C} 3$ ranged from 0.4 to 0.5 (table 6 ).

\section{Discussion}

The sources for the distribution of surface sediments in the bay have been previously reported by Siddique (1967), Goldberg and Griffin (1970), Kolla and Rao (1990). According to them, the peninsular India is the major source of these river borne sediments which form a significant fraction in the bay. The sediment distribution map given by Siddique (1967) reveals the presence of more than $75 \%$ of clay in the bay. Sand and silty clays are found to occur as a narrow zone along the coasts while silty sediments occupy a thin margin along the shelf. However, in the present study, sand is dominant in majority of the sample sites. The northern side of the region has very less clay content and is covered by a mosaic of medium and coarse sand. The mouth of River Palar shows significant coarse silt content which is also reported by Selvaraj et al. (2004). The southern side is blanketed

Table 6. Trace element distribution in the core sediments.

\begin{tabular}{|c|c|c|c|c|c|c|c|c|c|c|c|c|}
\hline $\begin{array}{l}\text { Sample } \\
\text { id }\end{array}$ & $51 \mathrm{~V}$ & $52 \mathrm{Cr}$ & $55 \mathrm{Mn}$ & $59 \mathrm{Co}$ & $60 \mathrm{Ni}$ & $65 \mathrm{Cu}$ & $66 \mathrm{Zn}$ & $90 \mathrm{Zr}$ & $208 \mathrm{~Pb}$ & $232 \mathrm{Th}$ & $238 \mathrm{U}$ & $\mathrm{V} / \mathrm{Cr}$ \\
\hline C1-1 & 46.23 & 92.91 & 1140.00 & 27.41 & 57.03 & 78.07 & 375.90 & 533.10 & 37.60 & 29.94 & 2.39 & 0.50 \\
\hline C1-5 & 54.25 & 123.00 & 1220.00 & 32.20 & 62.18 & 28.43 & 508.80 & 478.60 & 70.46 & 27.34 & 3.45 & 0.44 \\
\hline C1-8 & 50.71 & 110.50 & 1152.00 & 33.30 & 58.47 & 23.56 & 546.50 & 466.00 & 43.31 & 24.25 & 3.96 & 0.46 \\
\hline C1-10 & 64.10 & 132.20 & 1315.00 & 36.85 & 79.20 & 33.10 & 911.00 & 489.90 & 59.73 & 27.40 & 4.84 & 0.48 \\
\hline C1-13 & 57.04 & 115.60 & 1232.00 & 34.29 & 72.93 & 36.18 & 681.00 & 379.70 & 54.99 & 34.68 & 3.65 & 0.49 \\
\hline C1-15 & 61.86 & 130.80 & 1299.00 & 36.78 & 80.49 & 30.55 & 708.40 & 345.00 & 57.12 & 24.56 & 4.04 & 0.47 \\
\hline C1-18 & 52.31 & 110.20 & 1212.00 & 34.49 & 65.29 & 22.47 & 576.80 & 323.70 & 47.79 & 17.88 & 2.99 & 0.47 \\
\hline C1-20 & 50.76 & 105.10 & 1228.00 & 33.29 & 61.97 & 23.73 & 566.00 & 289.40 & 50.07 & 23.38 & 3.06 & 0.48 \\
\hline Mean & 54.66 & 115.04 & 1224.75 & 33.58 & 67.20 & 34.51 & 609.30 & 413.18 & 52.63 & 26.18 & 3.55 & 0.48 \\
\hline Std. dev & 6.03 & 13.30 & 61.39 & 2.99 & 9.18 & 18.27 & 159.21 & 89.79 & 10.26 & 4.96 & 0.76 & 0.45 \\
\hline C3-1 & 31.70 & 60.91 & 739.90 & 25.18 & 46.09 & 20.76 & 745.70 & 203.90 & 61.84 & 17.13 & 2.56 & 0.52 \\
\hline C3-5 & 28.77 & 51.13 & 661.30 & 22.58 & 39.99 & 15.46 & 793.20 & 140.00 & 52.91 & 18.06 & 2.16 & 0.56 \\
\hline C3-8 & 35.18 & 76.14 & 855.00 & 30.15 & 62.70 & 30.07 & 1022.00 & 234.00 & 286.10 & 27.47 & 3.80 & 0.46 \\
\hline C3-10 & 48.67 & 112.20 & 1071.00 & 43.16 & 97.60 & 51.06 & 2649.00 & 233.20 & 63.14 & 31.96 & 4.82 & 0.43 \\
\hline C3-13 & 37.77 & 73.18 & 968.30 & 36.49 & 61.11 & 31.02 & 1437.00 & 227.40 & 64.36 & 31.44 & 4.14 & 0.52 \\
\hline C3-15 & 37.80 & 70.86 & 886.50 & 33.96 & 59.69 & 45.28 & 1689.00 & 189.20 & 101.10 & 21.79 & 4.60 & 0.53 \\
\hline C3-18 & 39.23 & 77.44 & 1031.00 & 37.69 & 63.24 & 35.32 & 1052.00 & 224.10 & 86.74 & 44.53 & 6.79 & 0.51 \\
\hline C3-21 & 27.34 & 47.49 & 647.10 & 23.45 & 38.82 & 22.64 & 1175.00 & 165.50 & 65.19 & 18.64 & 2.98 & 0.58 \\
\hline Mean & 35.81 & 71.17 & 857.51 & 31.58 & 58.66 & 31.45 & 1320.36 & 202.16 & 97.67 & 26.38 & 3.98 & 0.50 \\
\hline Std. dev & 6.80 & 20.07 & 162.74 & 7.48 & 18.75 & 12.19 & 621.64 & 34.79 & 77.72 & 9.43 & 1.48 & 0.34 \\
\hline
\end{tabular}


by medium and coarse sands in the inner shelf and fine sands are abundant in the outer shelf. These sands must have been carried to the deeper part by combined wave and current action (Van Rijn and Havinga 1993). The average standard deviation value of 1.04 indicates that the sediments are overall poorly sorted and texturally immature which is due to rapid transportation and fluctuating velocity conditions of the agent of deposition (Sahu 1964). The kurtosis values of the samples varied widely between platykurtic $(<0.61 \Phi)$ and very leptokurtic nature $(3 \Phi)$ reflecting the flow characteristics of the depositing medium (Baruah et al. 1997; Rajganapathi et al. 2012). The leptokurtic nature and negatively skewed values for samples with abundant sand content is in accordance with the findings of Friedman (1962). The samples with relatively more negatively skewed values suggest erosion or non-deposition and winnowing of sediments (Duane 1964), while the less number of positively skewed samples indicate removal of coarser fraction or introduction of finer sediments (Friedman 1961). Among the few samples showing positive skewness, only few are the depositional sites of finer fractions while the others show positive skewness owing to the prevailing high energy environment confirmed by the presence of sand (Sly et al. 1982). Thus the frequency distribution pattern of the sediments displays unimodal to bimodal character. Finer grain size deposition in the absence of river flow is attributed to the currents and wave activity or due to the input from minor rivers flowing in this region. Clay mineral studies were attempted by a few earlier workers such as Sastry et al. (1958), Subba Rao (1964), Ramamurthy and Shrivastava (1979), Subramanian (1980), Rao et al. (1988), Kolla and Rao (1990) and Ramaswamy et al. (1997) in order to deduce the source of the sediments. According to Subba Rao (1964), smectite is considered to be very high in the east coast of India with equal quantities of illite and chlorite and minor amounts of montmorillonite and kaolinite. Goldberg and Griffin (1970) also observed that the eastern bay had high smectite content, very high illite and high kaolinite content. Studies reveal that eastern Bay receiving its riverine sediments from Ganges and Brahmaputra witnessed higher amounts of illite and chlorite in their clay mineral assemblages while the sediments derived from the peninsular India showed high quantities of montmorillonite (Goldberg and Griffin 1970) and smectite content (Ramaswamy et al. 1997).
In the present study, clay mineral assemblage is characterized by higher amounts of illite, kaolinite, chlorite and minor amounts of smectite. The predominance of illite and moderate chlorite content suggests that they are derived as a result of mechanically weathered sedimentary, igneous and metamorphic rock formations (Chamley 1989) of the mainland. The significant amount of kaolinite is due to the extreme chemical weathering and leaching of rocks under tropical humid climate (Tripathi et al. 2007; Rajamani et al. 2009) more specifically, the weathering of Precambrian gneissic rocks of southern India (Das et al. 2013). Besides, the presence of smectite clays indicates the erosion and weathering of basaltic Deccan traps (Phillips et al. 2014).

According to Haque and Subramanian (1982) and many others, the REEs are more enriched in finer sediments. This is due to the high adsorption behaviour of heavy metals on the sediment surface (Rengarajan and Sarin 2004). The accumulation of REEs in the sediments can be due to use of fertilizers, mining activities and atmospheric deposition (Pan et al. 2002; Zhang et al. 2000; Tyler 2004). Based on the results, $\Sigma$ REE values of C3 are greater than $\mathrm{C} 1$ and both the cores showed a significant deviation compared to the $\Sigma$ REE value of PAAS (McLennan 1989) which is $184.76 \mathrm{ppm}$. The lower content of REEs in $\mathrm{C} 1$ is due to the presence of calcite in these sediments which dilutes their concentration (Antonina et al. 2013). The higher content of REEs in C3 indicates that they are supplied in addition to the terrigenous influx from the continental area (Prakash Babu et al. 2010; Deepulal et al. 2014) and suggest an alkaline environment (Ramesh et al. 2000). In the present study, the LREE content is greater than HREE content of the core sediments. Similarly, $\mathrm{La}_{\mathrm{n}} / \mathrm{Sm}_{\mathrm{n}}$ values $>1$ observed in $\mathrm{C} 1$ shows enrichment of LREEs while the $\mathrm{Gd}_{\mathrm{n}} / \mathrm{Yb}_{\mathrm{n}}>2$ values of C3 indicate depletion of HREEs in the cores. This is in agreement with Deepulal et al. (2014) who observed in his study that the LREEs are present in higher concentration than HREEs in the eastern continental shelf sediments. The higher LREE/HREE values obtained in this region suggest that hot, humid climatic conditions would have prevailed during the time of weathering (Xing and Dudas 1993). According to previous workers, positive Eu anomaly is observed when hydrothermal vents are present or due to enrichment of feldspars. However, the positive Eu anomaly in the samples is due to the feldspar concentration (Elderfield 1988; 
Murray et al. 1991) and weathering of source rocks (Ramesh et al. 2000). Besides, there is no evidence of hydrothermal activity in this region, thus ruling out the possibility of any hydrothermal input. The presence of feldspars is also supported by mineralogical results obtained from the present study. The average concentration of $\mathrm{Cr}, \mathrm{Ni}$ and $\mathrm{Co}$ in clay-rich sediments was higher than in sandy sediments due to their adsorption capacity. The higher $\mathrm{Pb}$, Th and $\mathrm{U}$ are ascribed to both natural and anthropogenic input. Also to understand the variations in paleoxygenated environment, $\mathrm{V}$ and $\mathrm{Cr}$ were chosen because vanadium is deposited under reducing conditions (Emerson and Huested 1991) and chromium is found in the detrital sediments. The $\mathrm{V} / \mathrm{Cr}$ values of $<2$ as observed in both the cores indicate that the study area is characterized by an oxic environment (Jones and Manning 1994).

\section{Conclusions}

The present study reveals that the sediment distribution pattern is dominated by medium sand and is characterized by unimodal and bimodal characters. The moderately sorted to moderately well sorted sand sediments and limited deposition of very fine sediments suggest high energy environment prevailing in the sample sites. A significant number of samples showing negative skewness indicate the erosional and winnowing activity in the area of interest. The vertical sediment distribution revealed abundance of clay in the offshore regions of Chennai and to some extent in Cuddalore. The core sediments with abundant clay witnessed more illite content than other clay minerals and thereby suggest that the source is terrigenous. The lower $\mathrm{REEE}$ values noticed in C1-off Chennai are attributed to the diluting activity of biogenic matter. The higher $\Sigma$ REE values in C3-off Cuddalore are due to an additional input of REEs from the land side. Positive Eu anomaly is due to the role of plagioclase feldspars in this region which is also confirmed by bulk mineralogical analyses. The trace elements showed good correlation with grain size with few exceptions. The paleoredox index using $\mathrm{V} / \mathrm{Cr}$ values indicates that the study site is marked by oxygenated conditions and has no major variations in the depositional environment.

\section{Acknowledgements}

The authors wish to thank the Ministry of Earth Sciences for funding the cruises, National Institute of Technology (NIOT), Vessel Management Cell for allowing us to use the research vessels $O R V$-Sagar Manjusha and ORV-Sagar Paschimi for sample collection and the crew members and scientists on board during the cruises. We are very grateful to avail the XRD and ICP-MS facility at Department of Earth Sciences, Pondicherry University.

\section{References}

Antonina A N, Shazili N A M, Kamaruzzaman B Y, Ong M C, Rosnan Y and Sharifah F N 2013 Geochemistry of the Rare Earth Elements (REE) distribution in Terengganu Coastal Waters: A study case from Redang Island Marine Sediment Open J. Mar. Sci. 3 154-159.

Balsinha M, Fernandes C, Oliveira A, Rodrigues A and Taborda R 2014 Sediment transport patterns on the Estremadura Spur continental shelf: Insights from grainsize trend analysis; J. Sea Res. 93 28-32.

Baruah J, Kotoky P and Sarma J 1997 Textural and geochemical study on river sediments: A case study on the Jhanji River, Assam, Assam; J. Indian Assoc. Sedimentol. 16 195-206.

Blott S J and Pye K 2001 GRADSTAT: A grain size distribution and statistics package for the analysis of unconsolidated sediments. Earth Surf. Proc. Land 26(11) 1237-1248.

Biscaye P E 1965 Mineralogy and sedimentation of recent deep-sea clay in the Atlantic Ocean and adjacent seas and oceans; Geol. Soc. Am. Bull. 76(7) 803-831, https://doi. org/10.1130/0016-7606(1965)76[803:MASORD]2.0.CO;2.

Borrego J, Lopez-Gonzalez N, Carro B and Lozano-Soria O 2004 Origin of the anomalies in light and middle REE in sediments of an estuary affected by phosphogypsum wastes (south-western Spain); Mar. Pollut. Bull. 49 10451053.

Brown G and Brindley G W 1980 X-ray diffraction procedures for clay mineral identification. In: Crystal structures of clay minerals and their X-ray identification, Monograph No. 5 (eds) Brindley G W and Brown G, Mineralogical Society, London, pp. 305-360.

Brunton G 1955 Vapor pressure glycolation of oriented clay minerals; Am. Min. 40 124-126.

Carver R E 1971 Procedures in sedimentary petrology; Wiley Inter-Science, John Wiley and Sons Inc., New York, $653 \mathrm{p}$.

Censi P, Incarbona A, Oliveri E, Bonomo S and Tranchida G 2010 Yttrium and REE signature recognized in Central Mediterranean Sea (ODP Site 963) during the MIS 6-MIS 5 transition; Palaeogeogr. Palaeoclimatol. Palaeoecol. 292 201-210.

Chamley H 1989 Clay sedimentology; Springer-Verlag, Berlin, 623p.

Das S S, Rai A K, Akaram V, Verma V, Pandey A C, Dutta K and Ravi Prasad G V 2013 Paleoenvironmental significance of clay mineral assemblages in the southeastern Arabian Sea during last $30 \mathrm{kyr} ;$ J. Earth Syst. Sci. 122(1) 173-185. 
Deepulal P M, Sujatha C H and Gireesh Kumar T R 2014 Distribution of REE's along south coast of India; Indian J. Geo. Mar. Sci. 43(1) 96-105.

Duane D B 1964 Significance of skewness in recent sediments, western Pamlico Sound, North Carolina; J. Sedim. Petrol. 34(4) 864-874.

Elderfield H 1988 The oceanic chemistry of the rare-earth elements; Phil. Trans. Roy. Soc. London A 325 105-126.

Emerson S R and Huested S S 1991 Ocean anoxia and the concentrations of molybdenum and vanadium in seawater; Mar. Chem. 34 177-196.

Flemming B W 2000 A revised textural classification of gravel-free muddy sediments on the basis of ternary diagrams; Cont. Shelf Res. 20 1125-1137.

Folk R L and Ward W C 1957 Brazos River Bar: A study of the significance of grain size parameters; J. Sedim. Petrol. 27(1) 3-27.

Friedman G M 1961 Distinction between dune, beach, and river sands from their textural characteristics; J. Sedim. Petrol. 31(4) 514-529.

Friedman G M 1962 On sorting, sorting coefficient and the $\log$ normality of the grain size distribution of sandstones; J. Geol. 70 734-753.

Friedman G M 1967 Dynamic processes and statistical parameters compared for size frequency distribution of beach river sands; J. Sedim. Petrol. 37(2) 327-354.

Friedman G M 1979 Differences in size distribution of populations of particles among sands of various origin; Sedimentology 26 859-862.

Goldberg E D and Griffin J J 1970 The sediments of the northern Indian Ocean; Deep-Sea Res. 17 513-537.

Haque M A and Subramanian V $1982 \mathrm{Cu}, \mathrm{Pb}, \mathrm{Zn}$ pollution of soil environment; CRC Critical Rev. Environ. Control 12 $13-90$.

Jones B and Manning D A C 1994 Comparison of geochemical indices used for the interpretation of paleo-redox conditions in ancient mudstones; Chem. Geol. 111(1-4) $111-129$

Kolla V and Rao N M 1990 Sedimentary sources in the surface and near-surface sediments of the Bay of Bengal; Geo. Mar. Lett. 10 129-136.

Mason C and Folk R L 1958 Differentiation of beach, dune, and aeolian flat environments by size analysis, Mustang Island, Texas; J. Sedim. Petrol. 28 211-226.

McLennan S M 1989 Rare earth elements in sedimentary rocks: Influence of provenance and sedimentary processes; In: Geochemistry and Mineralogy of Rare Earth Elements (eds) Lipin B R and McKay G A, Rev. Mineral., Mineralogical Society of America, Washington, D.C., 21 169-200.

Milliman J D 2001 River inputs; In: Encyclopedia of ocean sciences (eds) Steele J H, Turekian K K and Thorpe S A, Academic Press, 4, pp. 2419-2427.

Murray R W, Buchholtz ten Brink, M R, Brumsack H J, Gerlach D C and Russ III P G 1991 Rare earth elements in Japan sea sediments and diagenetic behaviour of Ce/Ce*: Results from ODP Leg 127; Geochim. Cosmochim. Acta 55(9) 2453-2466, https://doi.org/10.1016/ 0016-7037(91)90365-C.

Murthy K S R, Subrahmanyam A S, Murty G P S, Sarma K V L N S, Subrahmanyam V, Rao K M, Rani P S, Anuradha A, Adilakshmi B and Sridevi T 2006 Factors guiding tsunami surge at the Nagapattinam-Cuddalore shelf, Tamil Nadu, east coast of India; Curr. Sci. 90(11) 1535-1538.

Oliveri E, Neri R, Bellanca A and Riding R 2010 Carbonate stromatolites from a Messinian hypersaline setting in the Caltanissetta Basin, Sicily: Petrographic evidence of microbial activity and related stable isotope and rare earth element signatures; Sedimentology 57 142-161.

Pan J M, Zhou H Y, Hu C Y et al. 2002 Nutrient profiles in interstitial water and flux in water sediment interface of Zhejiang estuary of China in summer; Acta Oceanol. Sin. 24(3) 52-59 (in Chinese with English Abstract).

Passega R 1964 Grain size representation by CM patterns as a geological tool; J. Sedim. Petrol. 34(4) 830-847.

Pejrup M 1988 The triangular diagram used for classification of estuarine sediments: A new approach; In: Tideinfluenced sedimentary environments and facies (eds) de Boer P L, van Gelder A and Nio S D, Reidel, Dordrecht, pp. 289-300.

Phillips S C, Johnson J E, Underwood M B, Guo J, Giosan L and Rose K 2014 Long-timescale variation in bulk and clay mineral composition of Indian continental margin sediments in the Bay of Bengal, Arabian Sea, and Andaman Sea; Mar. Petrol. Geol. 58 117-138, https://doi.org/10. 1016/j.marpetgeo.2014.06.018.

Piper D Z 1974 Rare-earth elements in the sedimentary cycle: A summary; Chem. Geol. 14(4) 285-304.

Piper D Z, Perkins R B and Rowe H D 2007 Rare-earth elements in the Permian Phosphoric Formation: Paleo proxies of ocean geochemistry; Deep-Sea Res. Part II 54 1396-1413.

Prakash Babu C, Pattan J N, Dutta K, Basavaiah N, Ravi Prasad G V, Ray D K and Govil P 2010 Shift in detrital sedimentation in the eastern Bay of Bengal during the late Quaternary; J. Earth Syst. Sci. 119(3) 285-295.

Rajamani V, Tripathi J K and Malviya V P 2009 Weathering of lower crustal rocks in the Kaveri river catchment, southern India: Implications to sediment geochemistry; Chem. Geol. 265 410-419.

Rajganapathi V C, Jitheshkumar N, Sundararajan M, Bhat K H and Velusamy S 2012 Grain size analysis and characterization of sedimentary environment along Thiruchendur coast, Tamilnadu, India; Arab. J. Geosci. 1-12, https://doi.org/10.1007/s12517-012-0709-0.

Ramamurthy M and Shrivastava P C 1979 Clay minerals in the shelf sediments of the northwestern part of the Bay of Bengal; Mar. Geol. 33 M21-M32.

Ramaswamy V, Vijay Kumar B, Partibhan G, Ittekkot V and Nair R R 1997 Lithogenic fluxes in the Bay of Bengal measured by sediment traps; Deep-Sea Res. Part I 44(5) 793-810.

Ramesh R, Ramanathan A L, Ramesh S, Purvaja R and Subramanian V 2000 Distribution of rare earth elements and heavy metals in the surficial sediments of the Himalayan river system; Geochem. J. 34 295-319.

Rana S S, Nigam R and Panchang R 2007 Relict benthic foraminifera in surface sediments off central east coast of India as indicator of sea level changes; Indian J. Mar. Sci. 36(4) 355-360.

Rao V P, Reddy N P and Rao ChM 1988 Clay mineral distribution in the shelf sediments off the northern part of the east coast of India; Cont. Shelf Res. 8(2) 145-151. 
Reineck H-E and Siefert W 1980 Faktoren der Schlickbildung im Sahlenburger Watt und Neuwerker Watt; Die Kuste 35 $26-51$.

Rengarajan R and Sarin M M 2004 Distribution of rare earth elements in the Yamuna and the Chambal rivers, India; Geochem. J. 38 551-569.

Sahu B K 1964 Depositional mechanisms from the size analysis of clastic sediments; J. Sedim. Petrol. 34(1) 7383.

Sastry A V R, Poornachandra Rao M and Mahadevan C 1958 Differential thermal analysis of plastic clays from the deltaic regions of Godavari and Krishna rivers; Andhra Univ. Mem. Oceanogr. 2 61-68.

Selvaraj K, Ram Mohan V and Szefer P 2004 Evaluation of metal contamination in coastal sediments of the Bay of Bengal, India: Geochemical and statistical approaches; Mar. Pollut. Bull. 49(3) 174-185.

Siddique H N 1967 Recent sediments of Bay of Bengal; Mar. Geol. 5 249-291.

Sly P G, Thomas R L and Pelletier B R 1982 Comparison of sediment energy-texture relationships in marine and lacustrine environments; Hydrobiologia $91 \quad 71-$ 84.

Subba Rao M 1964 Some aspects of continental shelf sediments off east coast of India; Mar. Geol. 1(1) 5987.

Subramanian V 1980 Mineralogical input of suspended matter by Indian rivers into the adjacent areas of the Indian Ocean; Mar. Geol. 36 M29-M34.

Subramanian V, Richey J and Abbas N 1985 Geochemistry of river basins in the Indian subcontinent: Part II. Preliminary studies on the particulate $\mathrm{C}$ and $\mathrm{N}$ in the Ganga-Brahmaputra river system; Mitteilungen aus dem Geologisch Paläontologischen Institut der Universität Hamburg 58 513-518.

Taylor S R and McLennan S M 1985 The continental crust: Its composition and evolution; Blackwell Publishers, Oxford, 312p.

Toyoda K, Nakumara Y and Masuda A 1990 Rare earth elements of Pacific pelagic sediments; Geochim. Cosmochim. Acta. 54 1053-1103.

Tripathi J K, Ghazanfari P, Rajamani V and Tandon S K 2007 Geochemistry of sediments of the Ganga alluvial plain, evidence of large scale sedimentary recycling; Quat. Int. 159 119-130.

Tyler W S 1967 Testing sieves and their uses (Handbook 53); W. S. Tyler Co., Mentor, Ohio, 48p.

Tyler G 2004 Rare earth elements in soil and plant systems -A review; Plant Soil 267 191-206.

Udayaganesan P, Angusamy N, Gujar A R and Rajamanickam G V 2011 Surface microtextures of quartz grains from the central coast of Tamil Nadu; J. Geol. Soc. India 77 26-34.

Van Rijn L C and Havinga F J 1993 Transport of fine sands by currents and waves II; J. Water Port Coast 119(2) 123-143.

Visher G S 1969 Grain size distributions and depositional processes; J. Sedim. Petrol. 39(3) 1074-1106.

Xing B and Dudas M J 1993 Trace and rare earth element content of white clay soils of the Three River Plain, Heilongjiang Province, P.R. China; Geoderma 58(3-4) 181-199.

Zhang H, Feng J and Zhu W F 2000 Rare earth element distribution characteristics of biological chains in rare earth element - high background regions and their implications; Biol. Trace Elem. Res. 73 19-27. 